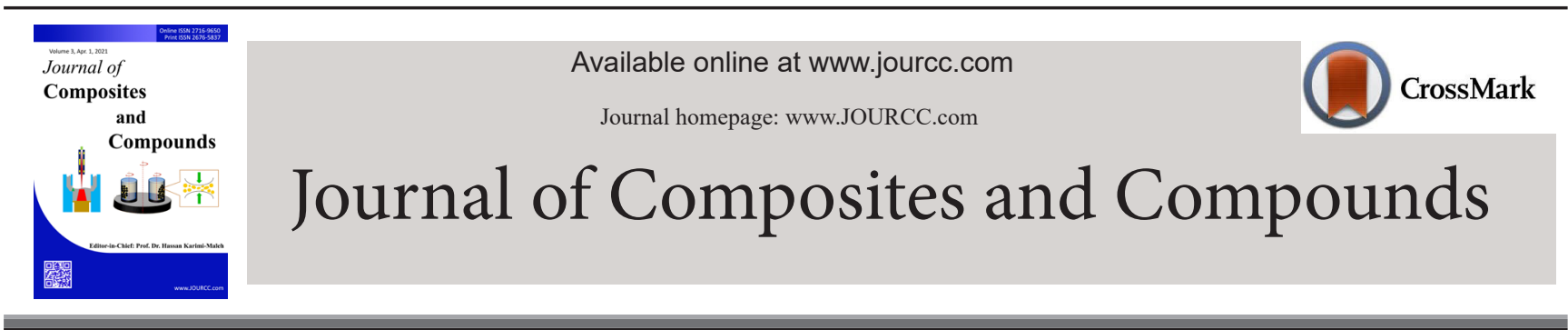

\title{
Application of different nanocatalysts in industrial effluent treatment: A review
}

\author{
Sara Eskandarinezhad ${ }^{*}$, Reza Khosravi ${ }^{b}$, Mohamadamin Amarzadeh ${ }^{c}$, Piyal Mondal ${ }^{d}$, \\ Fernando Jorge Correa Magalhães Filho ${ }^{e}$ \\ ${ }^{a}$ Department of Mining and Metallurgy, Yazd University, Yazd, Iran \\ ${ }^{b}$ Department of Chemical Engineering, Faculty of Engineering, Ferdowsi University of Mashhad, Mashhad, Iran \\ ${ }^{c}$ Department of Safety Engineering, Abadan Faculty of Petroleum Engineering, Petroleum University of Technology, Abadan, Iran \\ ${ }^{d}$ Department of Chemical Engineering, Indian Institute of Technology Guwahati, Guwahati, 781039, India \\ e Departamento de Engenharia Sanitária e Ambiental, Universidade Católica Dom Bosco, Campo Grande, Brazil
}

\section{A B S T R A C T}

The manufacturing, application, and design of chemical processes and products that minimize or remove waste Article history: and the use of dangerous and toxic reagents are referred to as green chemistry. Green chemistry is made up of Received 24 January 2021 twelve principles, one of which is catalysis. The role of catalysis is to accelerate the reaction by introducing a Received in revised form 11 February 2021 substance called a catalyst. Because of their high efficiency, productivity, activity, and selectivity, nanocatalysts Accepted 25 March 2021 have recently received many interests. Nanocatalysts are characterized by their high surface area to volume ratio, as well as their nanoscale forms and sizes. One of the significant applications of nanocatalysts is wastewater Keywords: and wastewater purification. Green and bio-synthesized nanocatalysts could be used efficiently to remove heavy Green chemistry metals, medicinal, organic, and inorganic pollutants from the wastewater systems. This paper reviews nanocata- Magnetic nanocatalyst lysts based on noble and magnetic nanocatalysts, as well as metal catalysts supported by organic polymers, and Noble nanocatalysts discusses their industrial effluent treatment mechanisms. Organic polymer-supported metal catalysts C2021 jourcc.

Peer review under responsibility of jourcc

\section{Table of contents}

1. Introduction

2. Nanocatalysts 43

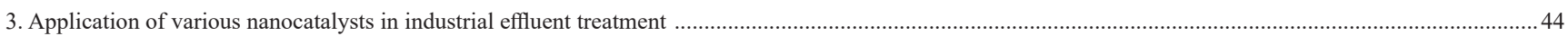

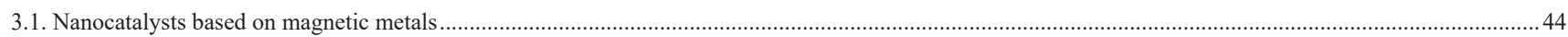

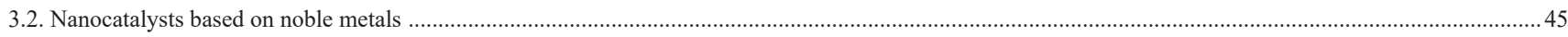

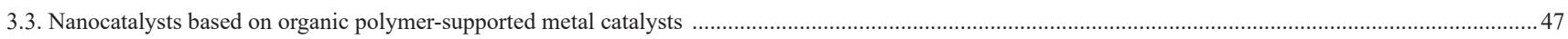

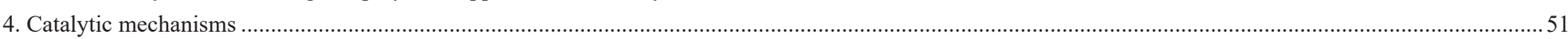

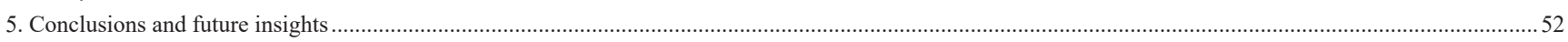

\section{Introduction}

The rapid expansion of various manufacturing sectors has adverse effects on the environment, particularly on the aquatic one, since most industries have wastewater composed of organic and inorganic pollutants with high concentration. As an example, various industries, including textile, paint, pharmaceutical, printing, leather, paper, and carpet, have produced daily a large number of aromatic pollutants, including many types of nitro compounds and dye. These industries would release large quantities of residual pollutants even if they were refined using conventional techniques [1-5]. Biodegradation of most of these aromatic pollutants dissolved in water is very hard, therefore becoming a longterm and direct toxic threat to aquatic and amphibian lives, animals, and microorganisms. Finally, this process affects humans since the lives on land depend on aquatic products and water, and some of these pollutants are extremely toxic, mutagenic, and carcinogenic [5-7].

Anastas and Warner in 1998 [8] proposed twelve principles called the principles of green chemistry to eliminate and reduce chemical substances and processes that are harmful to the environment. Fabrication and development of catalysts is an essential principle of green chemistry. These principles state that catalytic reagents are better than stoichiometric reagents since catalytic reagents are applied in small quantities and carry out one reaction several times, but stoichiometric reagents are 


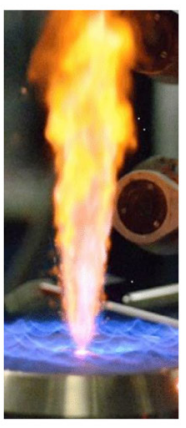

Spray flame

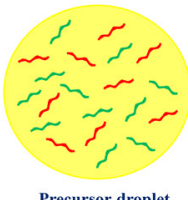

Precursor droplet

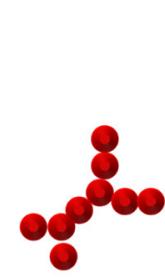

$\mathrm{MFe}_{2} \mathrm{O}_{4}$ nanoaggregates

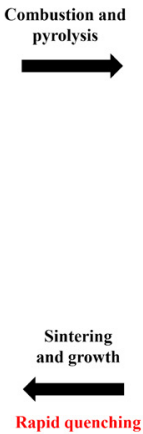

Rapid quenching

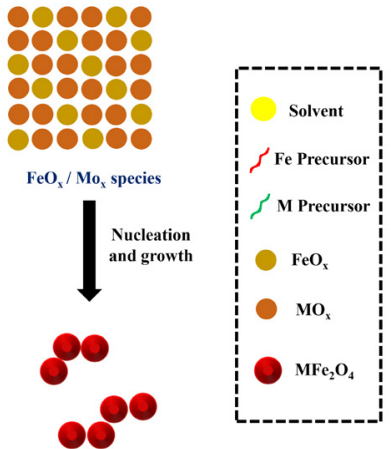

$\mathrm{MFe}_{2} \mathrm{O}_{4}$ nanoclusters

Fig. 1. Schematic illustration of the chainlike $\mathrm{MFe}_{2} \mathrm{O}_{4}$ nanoaggregates formation using spray flame.

applied further and work only once $[9,10]$. The base of these twelve green chemistry principles is to work similarly to nature. If the catalyst is not used, humans' necessary products, such as lubricants, paints, fuels, fibers, polymers, fine chemicals, medicines, will not be produced. Catalysis is a process that helps chemical transformations take place, allowing for the industrial processing of required products [11, 12]. Therefore, applying catalyst fabrication methods can be rendered more sustainable, cost-effective, and environmentally friendly. Soft catalysts such as crown ethers (as phase transfer catalysts) and zeolites have more industrial applications than heavy metal catalysts, which are usually non-recoverable [13]. Enzymatic catalysis is the greenest and most effective catalysis in nature among three classifications of enzymatic, heterogeneous, and homogeneous catalysis. Heterogeneous and homogeneous catalysis has some advantages and limitations; therefore, it is crucial to create a novel catalytic mechanism that is easily recoverable and active, like heterogeneous and homogeneous catalysis, respectively [14].

Nanomaterials offer promising properties originating from their high surface area $[15,16]$. Nanocatalysts have both advantages of the heterogeneous and homogeneous catalytic system [17, 18]. This system provides ease of catalyst recovery and separation as well as selective, and rapid chemical transformations with good product yield. One of the essential features of a catalyst is the ability to be recovered before being used in industry as green chemical manufacturing processes [19, 20]. One of the advantages of homogeneous catalysis is that the interaction between catalyst and reactants is significantly improved due to their nanosize and high surface area. Because of the catalyst's insolubility in the solvent, it is heterogeneous and hence it could be readily removed from the solution, which is one of the properties of heterogeneous catalysis [21]. Several authors have studied many magnetic [22-24], zinc $[25,26]$, cobalt $[27,28]$, and copper-based $[29,30]$ nanocatalysts. In this work, different nanocatalysts in industrial effluent treatment, including zinc-based nanocatalysts, cobalt-based nanocatalysts, copper-based nanocatalysts, and magnetic nanocatalysts, and their mechanism of action have been studied. Moreover, recent advancements have been reported.

\section{Nanocatalysts}

One of the first applications of nanoparticles is Catalysis. Several materials and elements such as silica, clays, titanium dioxide, iron, and aluminum have been applied as catalysts in nanoscale [31-35]. Nevertheless, there is no suitable explanation and the exact reason for nanoparticles' excellent catalytic behavior. The wide nanoparticles' surface area directly affects reaction rate and it can be a good reason for its catalytic performance [36]. The properties of structure, shape, and nanosize of any substance affect their catalytic performance. A better selectivity was achieved by well-adjusting nanocatalyst composition, including the use of supports, core-shell type, and bimetallic size and shape. By showing how the physical properties and preparation parameters associated with nanoparticles influence their catalytic characteristics, nanocatalysts with high activity, selectivity, and resilience can be designed. These advantages led to enabling industrial chemical reactions to produce less waste, consume less energy, and become more resource-efficient, reducing the environmental effect caused by applying chemical processes [37-39]. Nanoparticles are one of the most crucial catalysts for industrial purposes with many applications in chemical manufacturing, energy storage, and conversion. The heterogeneity and differences in shape and size of nanoparticles led to their special catalytic performance $[40,41]$.

According to the effect of nanomaterial intrinsic features on catalysis, the meaning and concept of nanocatalyst will be understood [42]. The intrinsic properties of nanomaterials that significantly affect the catalytic performance [21,43] could be classified as follows: quantities directly connected with the bond length, including binding energy, atomic density, as well as mean lattice constant. Surface densification and relaxation are caused by lattice contraction in a nano solid.

Quantities that relied on the cohesive energy per atom, including diffusion, the activation energy for chemical reactions, atomic dislocation, evaporation in a nano solid, phase transitions, critical temperature, Coulomb blockade, thermal stability, and self-organization growth.

The Hamiltonian, which defines the whole band structure, as well as attributes like photoemission, core level energy, and bandgap differs by the binding energy density in the relaxed continuum zone.

Qualities that result from the combined influence of the density of binding energy and energy of atomic cohesiveness including the magnetic performance of a ferromagnetic nano-solid, compressibility of a nano-solid, extensibility, surface energy, surface stress, Young's modulus, and mechanical strength.

\section{Application of various nanocatalysts in industrial effluent treatment}

\subsection{Nanocatalysts based on magnetic metals}

Gawande et al. [14] investigated the application of surface-functionalized nano magnetite supported nanoparticles in pharmaceutically significant, green chemistry, and catalysis reactions. Magnetite-supported metal nanocatalysts have been effectively applied in organic synthesis for various crucial reactions and they act as the catalytically active site [44-46]. The most important examples of these catalysts are $\mathrm{Ni}, \mathrm{Co}$, and Ferrites metal alloys. Some researchers have applied spinel ferrites for 


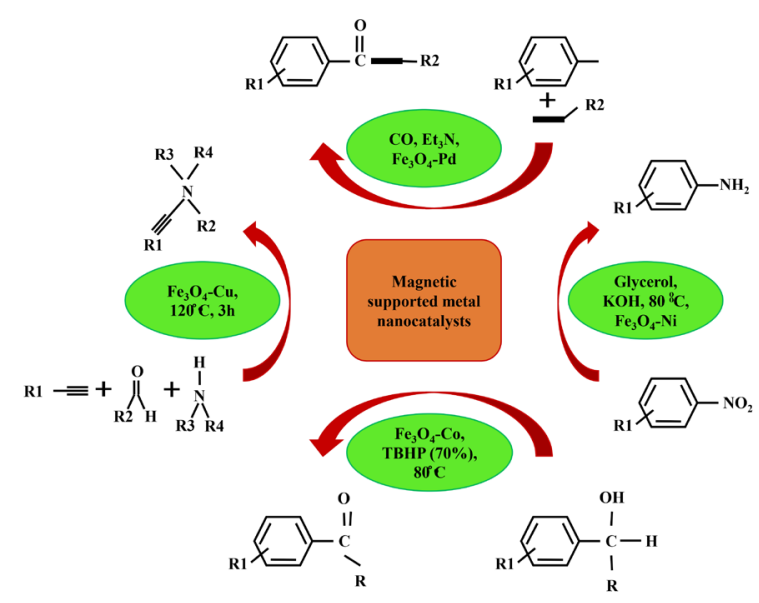

Fig. 2. Catalysis reactions of some organic components by metal nanoparticles supported by magnetite.

dyes and nitroarenes reduction. For example, Feng et al. [47] studied the $\mathrm{CuFe}_{2} \mathrm{O}_{4}$, which was prepared by hydrothermal technique; it has a high catalytic activity for nitrophenol reduction in the sodium borohydride presence. Li et al. [48] used the spray pyrolysis method to synthesize the chainlike spinel $\mathrm{MFe} 2 \mathrm{O} 4(\mathrm{M}=\mathrm{Cu}, \mathrm{Ni}, \mathrm{Co}$, and $\mathrm{Zn})$. (Fig. 1). It was revealed that $\mathrm{CuFe}_{2} \mathrm{O}_{4}$ has the best catalytic performance for the nitroaromatic reduction compared to $\mathrm{ZnFe}_{2} \mathrm{O}_{4}, \mathrm{CoFe}_{2} \mathrm{O}_{4}$, and $\mathrm{NiFe}_{2} \mathrm{O}_{4}$.

Goyal et al. [49] have studied the catalytic efficiency of nano ferrites of $\mathrm{MFe}_{2} \mathrm{O}_{4}(\mathrm{M}=\mathrm{Zn}, \mathrm{Cu}, \mathrm{Ni})$ as well as $\mathrm{Mn}$-doped $\mathrm{CoFe}_{2} \mathrm{O}_{4}$ catalysts for the 4-NP catalytic reduction [50]. These samples were provided by the sol-gel process. $\mathrm{CuFe}_{2} \mathrm{O}_{4}$ presented higher catalytic performance between the synthesized ferrites while pure $\mathrm{CoFe}_{2} \mathrm{O}_{4}$ was not active, but the addition of $\mathrm{Mn}$ ions improved its catalytic efficiency. The synergistic effect of the $\mathrm{Fe}^{3+}, \mathrm{Mn}^{3+}$, and $\mathrm{Co}^{3+}$, which were in the octahedral sites, could be accountable for improving catalytic activity. $\mathrm{CoMn}_{0.2} \mathrm{Fe}_{1.8} \mathrm{O}_{4}$ showed the highest catalytic performance. Kiran et al. [51] studied the $\mathrm{Bi}^{2+}$ catalytic performance substituted nanoparticles of $\mathrm{CoFe}_{2} \mathrm{O}_{4}$, which were synthesized by co-precipitation and combustion methods, and revealed that the sample synthesized by combustion technique showed better catalytic activity in comparison with the nanoparticles synthesized using the co-precipitation technique. Singh et al. [52] synthesized $\mathrm{Ni}^{2+}$-doped $\mathrm{CoFe}_{2} \mathrm{O}_{4}\left(\mathrm{Ni}_{x} \mathrm{Co}_{1-x} \mathrm{Fe}_{2} \mathrm{O}_{4}\right.$ nanoparticles by the reverse micelle method. Dey et al. [53] studied the cube-shaped magnetic $\mathrm{NiFe}_{2} \mathrm{O}_{4}$ nanoparticle for 4-nitrophenol (4-NP) catalytic reduction. Dhiman et al. [54] prepared several morphologies of $\mathrm{NiFe}_{2} \mathrm{O}_{4}$ hydrothermally using varying reaction conditions, solvents, additives, and precursors. It was reported that the catalytic performance of all the provided morphologies for reduction reactions depends on the surface area. The $\mathrm{NiFe}_{2} \mathrm{O}_{4}$ nano cord morphology showed the highest surface area and highest catalytic property. Papadas et al. [55] prepared three-dimensional mesoporous $\mathrm{BiFeO}_{3}$ using a process of nanoparticle templating, which in the first step involved the synthesis of polymer-assisted aggregating formation of 3-aminopropanoic acid stabilized $\mathrm{BiFeO}_{3}$ nanocrystals, accompanied by thermal decomposition to eliminate surfactant molecules . Catalysis reactions of some organic components by metal nanoparticles supported by magnetite are presented in Fig. 2.

Amir et al. [56] studied the degradation of organic dyes, including methylene blue (MB) and methyl orange (MO), using the recyclable magnetic nanocatalyst of $\mathrm{Fe}_{3} \mathrm{O}_{4} @$ His@ $\mathrm{Ag}$ in which histidine was applied as a linker. According to catalytic analysis, this nanocatalyst can lead to MB and MO degradation at the appropriate time. This material could also be recovered five times using magnetic separation while it maintains most of its activity. Kurtan et al. [57] prepared a magnetically recyclable nanocatalyst of $\mathrm{MnFe}_{2} \mathrm{O}_{4} @ \mathrm{SiO}_{2} @ \mathrm{Ag}$ by chemical reduction and co-precipitation method. The reduction of several azo compounds, including rhodamine $\mathrm{B}(\mathrm{RhB})$, eosin $\mathrm{Y}(\mathrm{EY}), \mathrm{MB}$, and $\mathrm{MO}$, as well as aromatic nitro compounds like 4-NP and 2-nitroaniline (2-NA), 4-nitroaniline (4-NA), was catalyzed by a magnetically recyclable Mn$\mathrm{Fe}_{2} \mathrm{O}_{4} @ \mathrm{SiO}_{2} @ \mathrm{Ag}$ nanocatalyst. Furthermore, the magnetic nanocatalyst exhibits high recyclability, with qualities that are maintained after multiple using cycles. Mohammadi et al. [58] studied the in situ and green synthesis of $\mathrm{Fe}_{3} \mathrm{O}_{4} @ \mathrm{SiO}_{2} \mathrm{Ag}$ magnetic nanocatalysts employing safflower (Carthamus tinctorius L.) flower extract with no surfactants or stabilizers. For the reduction of MO, MB, and 4NP, the catalytic activity of the resulting nanocatalyst was investigated at room temperature. To reduce $\mathrm{MB}, \mathrm{MO}$, and $4 \mathrm{NP}$, the noticeable rate constants were $0.09 \mathrm{~s}^{-1}$, $0.064 \mathrm{~s}^{-1}$, and $0.756 \mathrm{~min}^{-1}$, respectively. A magnet was used to recover the catalyst, which was then reused for multiple cycles without losing its function. Veisi et al. [59] studied the surface functionalization of $\mathrm{Fe}_{3} \mathrm{O}_{4}$ nanoparticles with thiol groups to immobilize $\mathrm{Ag}$ nanoparticles, resulting in $\mathrm{Fe}_{3} \mathrm{O}_{4} / \mathrm{SiO}_{2}-\mathrm{Pr}-\mathrm{S}-\mathrm{Ag}$ nanoparticles. $\mathrm{Fe}_{3} \mathrm{O}_{4} / \mathrm{SiO}_{2}-\mathrm{Pr}-\mathrm{S}-\mathrm{Ag} \mathrm{NPs}$ have excellent catalytic efficiency as a reusable nanocatalyst for the $\mathrm{MB}$, $\mathrm{RhB}$, and 4-NP degradation in an aqueous solution at room temperature. Ghosh et al. [60] investigated a convenient procedure for the synthesis of a new nanocatalyst containing $\mathrm{Ag}, \mathrm{CoFe}_{2} \mathrm{O}_{4}$, and mesoporous $\mathrm{TiO}_{2}$ nanoparticles for three essential reactivities: (i) photocatalytic MB degradation, (ii) 4-NP reduction, and (iii) styrene epoxidation. The prepared catalyst showed a high catalytic performance to these three reactions. Within 10 hours, they recorded a 98 percent conversion of styrene and a 95 percent selectivity of styrene oxide. The result showed that this catalyst reduced 4-nitrophenol in 4 minutes with $\mathrm{k}_{\text {app }}=1.08 \mathrm{~min}^{-1}$. When exposed to visible light for 60 minutes, the catalyst exhibited total photodegradation of MB. In addition, the catalyst was readily restored using a permanent magnet externally as well as exhibited excellent reusability. Najafinejad et al. [61] prepared Au nanoparticles supported on $\mathrm{Fe}_{3} \mathrm{O}_{4} @$ polyaniline, and their activity in eliminating MB and MO from aqueous systems was investigated. Two nanocatalyst concentrations were applied at room temperature to examine the impact of nanocatalyst dosage on the degradation rate of azo dyes. When azo dyes are degraded with $\mathrm{NaBH}_{4}$, the reaction is $10^{3}$ to $10^{4}$ times quicker than degrading without the nanocatalyst. A list of recent nanocatalysts based on magnetic metals for treating various industrial effluents is provided in Table. 1.

\subsection{Nanocatalysts based on noble metals}

The noble metals, such as $\mathrm{Pt}, \mathrm{Pd}, \mathrm{Ag}$, and $\mathrm{Au}$, make most catalysts for the reduction reaction, but their high cost has limited their practical applications [65-67]. Because metal-based catalysts can reduce their high surface energy, they can quickly aggregate with no effective protection or stabilization of the nanocatalysts, resulting in deterioration of their catalytic performance and decreased lifespan. [68-70]. For example, the aggregation of bimetallic NPs of Ag-Au occurs without protection by a surfactant of the triblock copolymer; at room temperature, the bimetallic NPs stabilized by surfactants can be stable for weeks $[71,72]$. The results showed that $\mathrm{Pd}$ and $\mathrm{Pt}$ have excellent adsorption energy properties [73, 74]. The microwave-polyol process was used to create Pd, Pt, Pd@Ag, and Pt@Ag nanoparticles, and the nano boxes of these core/shell systems prepared by galvanic replacement reactions showed optical properties. [75, 76]. Besides, Gu et al. [77] reported the photochemical creation of $\mathrm{Pd}, \mathrm{Pt}$, and Ag monometallic NPs supported on graphene/ $\mathrm{ZnO}$ and applied these multi-hybrid nano-architectures as electrocatalysts for $\mathrm{H}_{2} \mathrm{O}_{2}$. The free Ag NPs prepared by several various methods are also reported [78].

Salem et al. [79] prepared Pt@Ag and Pd@Ag core/shell nanoparticles using the citrate method in two steps (Fig. 3). To examine the catalytic performance of these nanostructures of core/shell, the Congo 
Table 1.

Nanocatalysts based on magnetic metals for the degradation of pollutants in wastewater

\begin{tabular}{|c|c|c|c|c|}
\hline Authors/Country & Nanocatalysts & Synthesis Methods & $\%$ removal/ reduction & Catalytic behaviors \\
\hline $\begin{array}{l}\text { Oliveira et al. [62] } \\
\text { Brazil }\end{array}$ & $\mathrm{TiO}_{2}: \mathrm{CoFe}_{2} \mathrm{O}_{4}$ & $\begin{array}{l}\mathrm{CoFe}_{2} \mathrm{O}_{4} \text { via Combus- } \\
\text { tion and } \mathrm{TiO}_{2}: \mathrm{CoFe}_{2} \mathrm{O}_{4} \\
\text { via Pechini method }\end{array}$ & $\begin{array}{l}\text { Degradation } \sim 100 \% \text { and } \\
\text { efficient mineralization of } \\
\text { diuron (DRN) }\end{array}$ & $\begin{array}{l}\text { Reducing the concentration of } \mathrm{CoFe}_{2} \mathrm{O}_{4} \text { improved the } \\
\text { photocatalytic systems mineralization. The photocatalytic } \\
\text { treatment decreased the toxicity of the system and ampli- } \\
\text { fied CE50 from } 1.5 \% \text { to } 14 \% \text {. }\end{array}$ \\
\hline $\begin{array}{l}\text { Mohamed et al. } \\
\qquad \text { [63] } \\
\text { Saudi Arabia }\end{array}$ & $\begin{array}{l}\mathrm{TiO}_{2} / \alpha-\mathrm{Fe}_{2} \mathrm{O}_{3} \text { nanocom- } \\
\text { posite }\end{array}$ & Co-precipitation & Degradation of MB $98 \%$ & $\begin{array}{c}\mathrm{TiO}_{2} / \alpha-\mathrm{Fe}_{2} \mathrm{O}_{3} \text { nanocomposites exhibited better photo- } \\
\text { catalytic performance compared to pure } \mathrm{Fe}_{2} \mathrm{O}_{3} \text { or } \mathrm{TiO}_{2} \\
\text { nanomaterials; increased } \alpha-\mathrm{Fe}_{2} \mathrm{O}_{3} \text { concentration enhanced } \\
\text { the activity. }\end{array}$ \\
\hline $\begin{array}{l}\text { Feng et al. [47] } \\
\text { China }\end{array}$ & $\mathrm{CoFe}_{2} \mathrm{O}_{4}$ & Hydrothermal technique & Nitrophenol reduction $\sim 95 \%$ & $\begin{array}{c}\text { Reduction happened in the presence of sodium borohy- } \\
\text { dride. }\end{array}$ \\
\hline $\begin{array}{l}\text { Li et al. [48] } \\
\quad \text { China }\end{array}$ & $\begin{array}{l}\text { Chainlike spinel } \mathrm{MFe}_{2} \mathrm{O}_{4} \\
(\mathrm{M}=\mathrm{Cu}, \mathrm{Ni}, \mathrm{Co} \text {, and } \mathrm{Zn})\end{array}$ & Spray pyrolysis method & $\begin{array}{l}\text { Nitroaromatic reduction } \\
\qquad \sim 100 \%\end{array}$ & $\begin{array}{l}\mathrm{CoFe}_{2} \mathrm{O}_{4} \text { has the best catalytic performance in reducing } \\
\text { nitroaromatic compared to } \mathrm{ZnFe}_{2} \mathrm{O}_{4}, \mathrm{CoFe}_{2} \mathrm{O}_{4} \text {, and } \mathrm{NiFe}_{2} \mathrm{O}_{4}\end{array}$ \\
\hline $\begin{array}{l}\text { Goyal et al. [49] } \\
\text { India }\end{array}$ & $\begin{array}{l}\mathrm{MFe}_{2} \mathrm{O}_{4} \text { nano ferrites }(\mathrm{M} \\
=\mathrm{Zn}, \mathrm{Cu}, \mathrm{Ni}), \mathrm{Mn} \text {-doped } \\
\mathrm{CoFe}_{2} \mathrm{O}_{4}\end{array}$ & Sol-gel method & 2-NP reduction $\sim 95 \%$ & $\begin{array}{c}\mathrm{Fe}^{3+}, \mathrm{Mn}^{3+} \text {, and } \mathrm{Co}^{3+} \text { enhanced the catalytic performance, } \\
\mathrm{CoFe}_{2} \mathrm{O}_{4} \text { was the best ferrite catalyst, } \mathrm{CoMn}_{0.2} \mathrm{Fe}_{1.8} \mathrm{O}_{4} \text { was } \\
\text { the best catalyst }\end{array}$ \\
\hline $\begin{array}{l}\text { Kiran et al. [51] } \\
\text { India }\end{array}$ & $\begin{array}{l}\mathrm{Bi}^{2+} \text { substituted nanoparti- } \\
\text { cles of } \mathrm{CoFe}_{2} \mathrm{O}_{4}\end{array}$ & $\begin{array}{l}\text { Co-precipitation and } \\
\text { combustion methods }\end{array}$ & $\begin{array}{l}\text { 4-NP to 4-AP reduction in } \\
2.25 \mathrm{~min}\end{array}$ & $\begin{array}{l}\text { Combustion method results had better catalytic perfor- } \\
\text { mance than co-precipitation process }\end{array}$ \\
\hline $\begin{array}{l}\text { Singh et al. [52] } \\
\text { India }\end{array}$ & $\begin{array}{l}\mathrm{Ni}^{2+} \text {-doped } \mathrm{CoFe}_{2} \mathrm{O}_{4}(\mathrm{Nix}- \\
\left.\mathrm{Co}_{1-\mathrm{x}} \mathrm{Fe}_{2} \mathrm{O}_{4}\right) \text { nanoparticles }\end{array}$ & Reverse micelle method & $\begin{array}{l}\text { Reduction of 4-nitrophenol, } \\
\text { degradation of Rhodamine } \\
\qquad \text { B } \sim 99 \%\end{array}$ & $\begin{array}{l}\text { Photo-oxidative degradation of Rhodamine } \mathrm{B}, \mathrm{NaBH}_{4} \text { was } \\
\text { used as the reducing agent. }\end{array}$ \\
\hline $\begin{array}{l}\text { Dey et al. [53] } \\
\text { India }\end{array}$ & $\begin{array}{l}\text { Cube-shaped magnetic } \\
\mathrm{NiFe}_{2} \mathrm{O}_{4} \text { nanoparticle }\end{array}$ & Novel method & $\begin{array}{l}\text { 4-nitrophenol (4-NP) catalyt- } \\
\text { ic reduction }\end{array}$ & $\begin{array}{l}\text { Effective, reusable nickel ferrite magnetic nanocatalyst } \\
\text { without implementing any functionalization, }\end{array}$ \\
\hline $\begin{array}{l}\text { Dhiman et al. [54] } \\
\text { India }\end{array}$ & $\begin{array}{l}\text { Several morphologies of } \\
\mathrm{NiFe}_{2} \mathrm{O}_{4} \text { hydrothermally }\end{array}$ & $\begin{array}{l}\text { Varying reaction } \\
\text { conditions, solvents, } \\
\text { additives, and precursors }\end{array}$ & $\begin{array}{l}\text { Degradation of anionic } \\
\text { remazol brilliant yellow } \\
\text { (RBY) } \sim 90 \% \text { and cationic } \\
\text { safranine-O }(\mathrm{SO})\end{array}$ & $\begin{array}{c}\mathrm{NiFe}_{2} \mathrm{O}_{4} \text { nano cord morphology had the highest surface area } \\
\text { and the best catalytic performance }\end{array}$ \\
\hline $\begin{array}{l}\text { Papadas et al. [55] } \\
\text { USA }\end{array}$ & $\begin{array}{l}\text { Three-dimensional meso- } \\
\text { porous } \mathrm{BiFeO}_{3}\end{array}$ & Nanoparticle templating & $\begin{array}{l}\text { Reduction of p-nitrophenol to } \\
\text { p-aminophenol with } \mathrm{NaBH}_{4} \text {, } \\
\qquad 98 \%\end{array}$ & $\begin{array}{l}\text { The MBFAs }\left(\mathrm{kapp}=0.018 \mathrm{~s}^{-1}\right) \text { reduction rate was two times } \\
\text { quicker than arbitrary } \mathrm{BiFeO}_{3} \mathrm{NP} \text { aggregates }\left(0.009 \mathrm{~s}^{-1}\right)\end{array}$ \\
\hline $\begin{array}{l}\text { Amir et al. [56] } \\
\text { Turkey }\end{array}$ & $\begin{array}{c}\mathrm{Fe}_{3} \mathrm{O}_{4} @ \mathrm{His} @ \\
\mathrm{Ag} \text { (histidine was applied } \\
\text { as a linker) }\end{array}$ & Hydrothermal method & $\begin{array}{l}\text { Complete degradation of } \mathrm{MO} \\
\text { and } \mathrm{MB}\end{array}$ & $\begin{array}{l}\text { Degradation of MB and MO at a reasonable time. Reusable } \\
\text { five times. }\end{array}$ \\
\hline $\begin{array}{l}\text { Kurtan et al. [57] } \\
\text { Turkey }\end{array}$ & $\begin{array}{c}\mathrm{MnFe}_{2} \mathrm{O}_{4} @ \\
\mathrm{SiO}_{2} @ \mathrm{Ag}\end{array}$ & $\begin{array}{l}\text { Chemical reduction and } \\
\text { co-precipitation method }\end{array}$ & $\begin{array}{l}\text { Complete reduction of } \\
\text { rhodamine B (RhB), eosin Y } \\
\text { (EY), MB, MO. Reduction of } \\
\text { 4-NP as well as 2-nitroaniline } \\
\text { (2-NA), 4-nitroaniline (4- } \\
\text { NA), and. }\end{array}$ & Remained unchanged after multiple uses \\
\hline $\begin{array}{l}\text { Mohammadi et } \\
\text { al. [58] } \\
\text { Iran }\end{array}$ & $\begin{array}{l}\text { Magnetic nanocatalyst of } \\
\qquad \mathrm{Fe}_{3} \mathrm{O}_{4} @ \mathrm{SiO}_{2}-\mathrm{Ag}\end{array}$ & $\begin{array}{l}\text { Green and in situ } \\
\text { synthesis, prepared by } \\
\text { safflower (Carthamus } \\
\text { tinctorius L.) flower } \\
\quad \text { extract }\end{array}$ & $\begin{array}{l}\text { Reduction of } 4-\mathrm{NP}, \mathrm{MO} \text {, and } \\
\text { MB at ambient temperature } \\
\qquad \sim 98 \%\end{array}$ & $\begin{array}{l}\text { The apparent constant rate for } \mathrm{MB}, \mathrm{MO} \text {, and the 4-NP } \\
\text { reduction was } 0.09 \mathrm{~s}^{-1}, 0.064 \mathrm{~s}^{-1} \text {, and } 0.756 \mathrm{~min}^{-1} \text {. Recover- } \\
\text { able by the magnet and reusable. }\end{array}$ \\
\hline $\begin{array}{l}\text { Ghosh et al. [60] } \\
\text { India }\end{array}$ & $\begin{array}{c}\text { Nanoparticles of Ag, } \\
\mathrm{CoFe}_{2} \mathrm{O}_{4} \text {, and mesoporous } \\
\mathrm{TiO}_{2}\end{array}$ & $\begin{array}{l}\text { EDTA precursor-based } \\
\text { method, }\end{array}$ & $\begin{array}{l}\text { Complete photocatalytic } \\
\text { degradation of MB, 4-NP re- } \\
\text { duction, styrene epoxidation } \\
\quad \sim 98.1 \%\end{array}$ & $\begin{array}{c}\text { Reduction of 4-NP with kapp }=1.08 \mathrm{~min}^{-1} \text { in } 4 \mathrm{~min} \text {, recov- } \\
\text { erable using magnet, reusable, and selectivity of styrene } \\
\text { oxide. }\end{array}$ \\
\hline $\begin{array}{l}\text { Najafinejad et al. } \\
\text { [61] } \\
\text { Iran }\end{array}$ & $\begin{array}{l}\text { Nanoparticles of } \mathrm{Au} \\
\text { supported on } \mathrm{Fe}_{3} \mathrm{O}_{4} @ \\
\text { polyaniline }\end{array}$ & $\begin{array}{l}\text { Reduction of } \mathrm{Au}^{3+} \text { using } \\
\text { a wild herbal extract } \\
\text { (Allium Sp) }\end{array}$ & $\begin{array}{l}\text { Reduce MB and } \mathrm{MO} \text { from } \\
\text { aqueous solutions }\end{array}$ & $\begin{array}{c}\text { Degradation of azo dyes with } \mathrm{NaBH}_{4} \text { was } 10^{3} \text { to } 10^{4} \\
\text { times quicker than degradation without employing the } \\
\text { nanocatalyst. }\end{array}$ \\
\hline $\begin{array}{l}\text { Ranjith et al. [64] } \\
\text { Taiwan }\end{array}$ & $\begin{array}{l}\text { Hybrid } \mathrm{rGO}-\mathrm{TiO}_{2} / \mathrm{Co}_{3} \mathrm{O}_{4} \\
\text { nanocomposite }\end{array}$ & Co-precipitation & $\begin{array}{l}\text { High reduction of MB and } \\
\text { crystal violet dye }\end{array}$ & $\begin{array}{l}\text { Compared to crystal violet dye, the decolorization of the } \\
\text { MB dye was higher with reduced time. } \mathrm{rGO} / \mathrm{TiO}_{2} / \mathrm{Co}_{3} \mathrm{O} \\
\text { catalyst could be applied to treat a variety of industrial dyes }\end{array}$ \\
\hline $\begin{array}{l}\text { Veisi et al. [59] } \\
\text { Iran }\end{array}$ & $\begin{array}{l}\text { Nanoparticles of } \mathrm{Fe}_{3} \mathrm{O}_{4} / \\
\mathrm{SiO}_{2}-\mathrm{Pr}-\mathrm{S}-\mathrm{Ag} . \mathrm{Fe}_{3} \mathrm{O}_{4} / \mathrm{SiO}_{2}- \\
\text { Pr-S-Ag NPs }\end{array}$ & $\begin{array}{l}\text { Surface modification of } \\
\text { nanoparticles of } \mathrm{Fe}_{3} \mathrm{O}_{4} \\
\text { with thiol groups for the } \\
\text { immobilization of } \mathrm{Ag} \\
\text { nanoparticles }\end{array}$ & $\begin{array}{l}\text { Degradation of MB, RhB, } \\
\text { and 4-NP high efficiently } \\
\text { decolorized the dyes. }\end{array}$ & $\begin{array}{l}\text { Significant catalytic performance with } \mathrm{NaBH}_{4} \text { in the water } \\
\text { at ambient temperature, recyclable }\end{array}$ \\
\hline
\end{tabular}




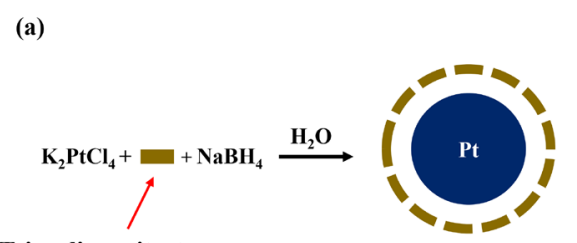

Tri-sodium citrate

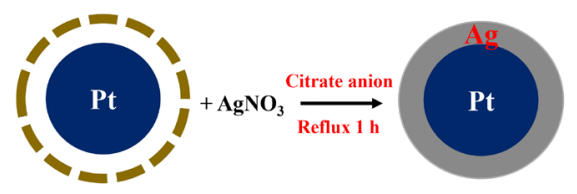

(b)

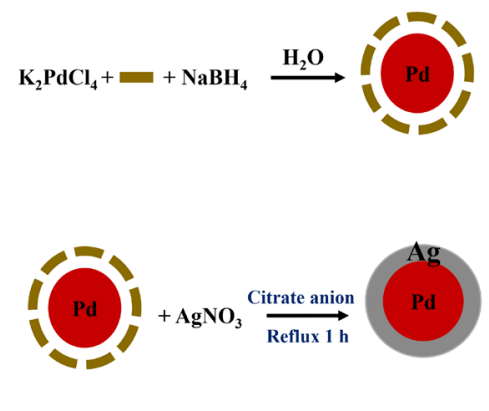

Fig. 3. Synthesis method of Pt@ $\mathrm{Ag}$ and $\mathrm{Pd} @ \mathrm{Ag}$ core/shell.

red dye reductive degradation was selected. The electrons move from the reducing agent $\left(\mathrm{NaBH}_{4}\right)$ to the dye molecules through nanocatalysts, which serve as electron mediators. After four reaction cycles, the Pd@ Ag nanocatalyst remained catalytically active. These results can be viewed as a cost-effective way to protect the environment by avoiding dye contamination in water supplies.

Moradi et al. [80] used the precipitation-decomposition method to create a range of $\mathrm{Ag}-\mathrm{ZnO} / \mathrm{CNT}$ nano photocatalysts with addition of multi-wall carbon nanotubes. The photocatalytic degradation of the Acid Orange 7 dye under visible light was used to determine the catalytic activity. As compared to the nanocomposite of $\mathrm{Ag}-\mathrm{ZnO}$ and pure $\mathrm{ZnO}$, the nano photocatalyst of $\mathrm{Ag}-\mathrm{ZnO} / \mathrm{CNT}$ with five wt. percent multi-wall carbon nanotubes loading had excellent photocatalytic activity. The efficient separation of pairs of electron hole on $\mathrm{Ag}-\mathrm{ZnO} / \mathrm{CNT}$ was related to improved photocatalytic performance. Duan et al. [81] synthesized the recyclable and high-performance nanocatalysts, which are composed of small, well-dispersed Ag nanoparticles that are immobilized on a Cu-based metal-organic substrate (MOF-199s) supported by CCFs (carboxymethylated cellulose fibers). The catalytic activity of AgNPs@ MOF-199s/CCFs catalysts for the reduction of 4-nitrophenol to 4-aminophenol showed a high catalytic efficiency. Enhanced dispersion, the porous catalyst structures, and small particles of Ag stabilized by the MOF-199 s cause the high catalytic activity. Applying cellulose fiber led to the facilitation of the sustainability and reuse of nanohybrid catalysts revealing high and stable reusability of $>91 \%$ after five cycles.

Bao et al. [81] studied a one-pot method and used co-reduction growth in polyol mixture to synthesize amino-functionalized $\left(-\mathrm{NH}_{2}\right)$ graphene oxide (GO-) supported networked nanowires of Pd-Ag. The results showed effective catalytic activity with superior recovering efficiency at ambient temperature $\left(25^{\circ} \mathrm{C}\right)$ for catalytic $\mathrm{Cr}(\mathrm{VI})$ reduction using the $\mathrm{H}_{2}$ source of formic acid. The electron transfer from amino and $\mathrm{Ag}$ to Pd enhances Pd electron density, which improves the decomposition of formic acid and the reduction of $\mathrm{Cr}(\mathrm{VI})$. The catalytic reduction rate constant of $\mathrm{Pd}_{3} \mathrm{Ag}_{1} / \mathrm{GO}-\mathrm{NH}_{2}$ is $0.0768 \mathrm{~min}^{-1}$, showing higher value compared to the monometallic $\mathrm{Pd} 3 \mathrm{Ag} 1 / \mathrm{GO}$ and $\mathrm{Pd} / \mathrm{GO}-\mathrm{NH} 2$ catalytic reduction rate constants. Iqbal et al. [82] created a new form of recyclable, ecologically safe, and convenient cerium-doped magnesium-aluminum-layered double hydroxide (MgAl-LDH) nanocatalyst, known as MgAlCe-LDH@Au. It was fabricated by adding Au nanoparticles with an approximate diameter of $3 \mathrm{~nm}$ on $\mathrm{MgAlCe}-\mathrm{LDH}$ support by in situ reductions of $\mathrm{HAuCl}_{4}$ utilizing $\mathrm{NaBH}_{4}$. This nanocatalyst shows very considerable activity in the 4-nitrophenol reductive degradation by $\mathrm{NaBH}_{4}$ with $k_{\text {app }}=0.041 \mathrm{~s}^{-1}$ (rate constant) and TOF= $1.2 \times 10^{6} \mathrm{~h}^{-1}$ (catalyst turnover frequency); at ambient temperature $\left(25^{\circ} \mathrm{C}\right)$ and air pressure, the reactions took place in an aqueous system.MgAlCe-LDH@Au nano- catalysts can be recovered and they can keep their original performance after seven catalytic processes.MgAlCe-LDH@Au is also an effective catalyst for the reductive breakdown of usual organic dyes, such as rhodamine $6 \mathrm{G}(\mathrm{R} 6 \mathrm{G})$, rhodamine $\mathrm{B}$, methylene blue, methyl orange, and Congo red that led to increased values of TOFs to $3.2 \times 10^{4} \mathrm{~h}^{-1}$. Sahoo et al. [83] applied a simple one-pot production of trimetallic porous Au@, Pd@Ru nanoparticles at ambient temperature. The trimetallic nanoparticles exhibited excellent catalytic performance in reducing p-nitrophenol and the breakdown of many azo dyes. The method was applied to eliminate color from wastewater using catalytic degradation of azo dyes.

Nasrollahzadeh et al. [84] used a structurally described furfural with a 3-aminopropyltriethoxysilane long tail to immobilize palladium nanoparticles on $\mathrm{NH}_{2}$-modified zeolite (Zeo) particles carrying a heterocyclic ligand. At room temperature $\left(25^{\circ} \mathrm{C}\right)$ in aqueous solutions, $\mathrm{NH}_{2}$ modified $\mathrm{Zeo} / \mathrm{Pd}$ was produced as a reusable, highly active, and sustainable nanocatalyst to reduce Nigrosin (NS), MB, RhB, 4-NP, 2,4-dinitrophenylhydrazine (2,4-DNPH), potassium hexacyanoferrate(III) $\left(\mathrm{K}_{3}\left[\mathrm{Fe}(\mathrm{CN})_{6}\right]\right)$, and $\mathrm{Cr}(\mathrm{VI})$. UV-Vis spectroscopy was used to evaluate the rate of removal of these toxicants with $\mathrm{NH}_{2}$ modified nanocatalyst of $\mathrm{Zeo} / \mathrm{Pd}$ using formic acid $(\mathrm{HCOOH})$ and sodium borohydride $\left(\mathrm{NaBH}_{4}\right)$ at ambient temperature $\left(25^{\circ} \mathrm{C}\right)$, as well as the nanocatalyst's ability to be recovered eight times without remarkable reduction of catalytic performance. Yan et al. [85] used the one-pot solvothermal method to make bimetallic Pt-rhodium alloyed (PtRh ANMPs) nanomultipods in oleylamine (OAm), using co-structure-directing agents of cetyltrimethylammonium chloride (CTAC) and creatinine. The prepared nanocatalyst showed remarkable catalytic properties to reduce $\mathrm{RhB}$ and 4-NP by $\mathrm{NaBH}_{4}$. In similar conditions, the prepared catalyst exhibited a highly facilitated TOF $=1.0 \times 10^{-3} / 0.44 \times 10^{-3} \mathrm{~mol} \mathrm{~g}^{-1} \mathrm{~min}^{-1}$ and $\mathrm{k}=0.209 / 0.354 \mathrm{~min}^{-1}$ for $\mathrm{RhB}$ and 4-NP reduction versus industrial Pt black. Table 2 shows a list of recent nanocatalysts based on noble metals for treating various industrial effluents.

\subsection{Nanocatalysts based on organic polymer-supported metal catalysts}

Because of their porous network structures and functionalities, polymer hydrogels were used as metal nanoparticle carrier systems [104]. They could be produced by several polymerization techniques, including polymerizations $[105,106]$, free-radical [107, 108], and ionic [109, $110]$ based on convenient and low-cost solution routes. As an example, a core-shell microgel containing a shell of cross-linked poly(N-isopropyl acrylamide) (PNIPA) and solid polystyrene (PS) core was applied to stabilize a nanocatalyst of Pd [111]. A spherical polyelectrolyte brushbased scheme with poly ((2-methylpropenoyloxyethyl) trimethylammonium chloride) long chains as a shell and a solid PS core was quantitatively contrasted to the microgel-based process [112]. The results 
Table 2.

Nanocatalysts based on noble metals for the degradation of pollutants in wastewater

\begin{tabular}{ccccc}
\hline Authors/ Country & Nanocatalysts & Synthesis methods & $\begin{array}{c}\text { \% removal/ } \\
\text { reduction }\end{array}$ & Catalytic behaviors \\
\hline $\begin{array}{c}\text { Katoch et al. [87] } \\
\text { India }\end{array}$ & $\mathrm{Bi}_{2} \mathrm{O}_{3}$ & Microflow & Degradation of $\mathrm{MO} \sim 96 \%$ & $\begin{array}{c}\mathrm{Bi}_{2} \mathrm{O}_{3} \text { nanoparticles exhibited excellent stability after three } \\
\text { cycles indicating coated microreactors in photocatalysis } \\
\text { reusability. }\end{array}$
\end{tabular}

\begin{tabular}{|c|c|c|c|}
\hline $\begin{array}{l}\text { Dang et al. [88] } \\
\text { China }\end{array}$ & $\begin{array}{l}\mathrm{CuCl}_{2} \text { nanoflake } \\
\text { film grown on } \\
\text { the top surface of } \\
\text { nanoporous anodic } \\
\text { alumina substrate } \\
(\text { nano-PAA-CuCl })\end{array}$ & Self-assembly approach & $\begin{array}{l}\text { Degradation of } \mathrm{MO} \sim 95 \% \\
\quad \text { and } \mathrm{MB} \sim 100 \%\end{array}$ \\
\hline $\begin{array}{c}\text { Rehman et al. [89] } \\
\text { Saudi Arabia }\end{array}$ & $\begin{array}{c}\mathrm{Ce} \& \mathrm{Zn} \text { doped } \mathrm{CuO} \\
\text { nanocatalyst }\end{array}$ & Co-precipitation & Degradation of $\mathrm{MO} \sim 81 \%$ \\
\hline $\begin{array}{c}\text { Dehghan et al. [90] } \\
\text { Iran }\end{array}$ & $\mathrm{ZnO} / \mathrm{rGO}$ & Chemical deposition & $\begin{array}{c}\text { Removal of Metalaxyl (MX) } \\
\sim 99 \%\end{array}$ \\
\hline
\end{tabular}

Dosti et al. [91]

Iran

Shelar et al. [92]

India

Ikram et al. [93]

Pakistan

Nasrollahzadeh et al.

Iran

Khoshnamvand et al.

[95]

China

Kumar et al. [96]

Ecuador

Garol et al. [97]

India

Salehi et al. [98]

Iran

Khan et al. [99]

Pakistan

Ganesh et al. [100]

South Korea

Prasad et al. [101]

India

Rajaendaran et al. [102]

India
ZnO NPs

Pd NPs

Ag-doped $\mathrm{ZnO}$

Ag decorated $\mathrm{MoS}_{2}$ nano pedals

$\mathrm{Ag} / \mathrm{MgO}$ nanocomposite

Ag NPs

Ag NPs

Pd NPs

Pd/RGO NPs

ZnO-NPs

$\mathrm{ZnO} \mathrm{Np}$

Green synthetic strategy

Ag-Mo/CuO NPs
Green synthesis using Abelmoschus esculentus

Adopting hydrothermal approach

Green synthesis

Biosynthesis

Green synthesis

Chemical deposition

Green synthesis

$$
\text { esculentus }
$$

Biogenic synthesis
Reduction of $\mathrm{Cr}(\mathrm{VI}) \sim 99 \%$

and $\mathrm{Cr}$ (III) precipitation

$\sim 96 \%$

Degradation of MB $\sim 65$ $95 \%$

\section{Dye degradation in the presence of $\mathrm{NaBH}_{4}$

$$
\sim 100 \%
$$

Complete and excellent reduction of $\mathrm{MB}, 4-\mathrm{NPMO}_{2}$, and 4-DNPH$$
\sim 100 \%
$$

Reduction of 4-NP, and antioxidant activity against DPPH, and ABTS+ $\sim 99 \%$

Reduction of MB $\sim 29 \%$ in 1 hour

Complete reduction of 4-NP, $\mathrm{MO}$, and $\mathrm{MB}$

Reduction of MB, MO, and textile dye degradation $\sim 91 \%$

Reduction MB 96\%

Degradation MB 100\%, Complete degradation of rhodamine B. Degradation of Congo red, and MO

Photodegradation of MB $\sim 99 \%$ rhodamine B $\sim 99 \%$

Synozol Navy Blue-KBF
Applicable in Fenton-like reaction as an effective process for wastewater treatment.

The photocatalyst of binary metal-doped $\mathrm{CuO}$ exhibited excellent photocatalytic performance for the treatment of toxic industrial effluents.

The MX toxicity was dropped from 51 to 15 within $96 \mathrm{~h}$. The photocatalytic performance was reduced by nitrate and phosphate ions but remained constant in the presence of other water anions.

Electrochemical cells could perform in-situ total free chlorine production and chromium removal concurrently.

The photocatalytic performance increase with the increase of concentration of dopant.

Excellent potential for removing hazardous toxins, including tannery pollutants and synthetic dyes, from industrial effluents.

The $\mathrm{Ag} / \mathrm{MgO}$ system was reusable, highly stable, with excellent catalytic performance.

Ag nanoparticles exhibited excellent antioxidant activity against ABTS and DPPH free radicals and efficient catalytic performance in 4-NP reduction to 4-AP.

Exhibited effective photocatalytic activity to remove MB dye $\left(5 \mathrm{mg} . \mathrm{L}^{-1}, \mathrm{k}=0.00707788 \mathrm{~min}^{-1}\right)$.

Excellent catalytic reduction performance for all organic contaminants; the occurrence of complete reduction in $10 \mathrm{~min}$.

These nanoparticles have excellent catalytic reduction activity.

Removed the dye in $159 \mathrm{~min}$, potential to have various photocatalytic and biological applications.

These green prepared nanoparticles of $\mathrm{ZnO}$ could be effective photocatalysts and anti-microbial for dye degradation and eliminating pathogenic microbes in industrial effluents.

$\mathrm{ZnO}$ nanoparticles are applied in selective photodegradation of the target cationic dyes.

The photocatalytic performance by AzI-MACO (99\%) was higher than that of AzI-MCO (88\%), AzI-ACO (74\%), AzI-CO (52\%), and CO (39\%) nanoparticles. 


\begin{tabular}{|c|c|c|c|c|}
\hline Authors/ Country & Nanocatalysts & Synthesis methods & $\begin{array}{l}\% \text { removal/ } \\
\text { reduction }\end{array}$ & Catalytic behaviors \\
\hline $\begin{array}{l}\text { Salem et al. [79] } \\
\text { Egypt }\end{array}$ & $\begin{array}{l}\mathrm{Pt} @ \mathrm{Ag} \text { and Pd@Ag } \\
\text { core } / \text { shell }\end{array}$ & Citrate method in two steps & $\begin{array}{c}\text { Congo red dye reductive } \\
\text { degradation } \\
\sim 85 \%\end{array}$ & $\begin{array}{l}\text { NaBH4 was used as a reducing agent; nanocatalyst was } \\
\text { catalytically stable after four cycles }\end{array}$ \\
\hline $\begin{array}{l}\text { Moradi et al. [80] } \\
\text { Iran }\end{array}$ & $\mathrm{Ag}-\mathrm{ZnO} / \mathrm{CNT}$ & $\begin{array}{l}\text { Method of precipitation-- } \\
\text { decomposition }\end{array}$ & $\begin{array}{l}\text { Acid Orange } 7 \text { dye photo- } \\
\text { catalytic degradation under } \\
\text { visible light } \sim 100 \%\end{array}$ & $\begin{array}{l}\text { Improved photocatalytic activity due to effective separa- } \\
\text { tion of pairs of electron-hole on } \mathrm{Ag}-\mathrm{ZnO} / \mathrm{CNT} \text { compared } \\
\text { to the nanocomposite of } \mathrm{Ag}-\mathrm{ZnO} \text { and the pure } \mathrm{ZnO} \\
\text { reusable }\end{array}$ \\
\hline $\begin{array}{l}\text { Iqbal et al. [83] } \\
\text { China }\end{array}$ & MgAlCe-LDH@Au & $\begin{array}{l}\text { Au nanoparticles loading } \\
\text { on } \mathrm{MgAlCe}-\mathrm{LDH} \text { by an in } \\
\text { situ reductions of } \mathrm{HAuCl}_{4}\end{array}$ & $\begin{array}{l}\text { Degradation of 4-nitro- } \\
\text { phenol } \sim 100 \% \text {, Complete } \\
\text { degradation of rhodamine } \\
\text { 6G (R6G), RhB, Congo red, } \\
\text { MO, and MB }\end{array}$ & $\begin{array}{l}\text { The reactions were in an aqueous system at room tempera- } \\
\text { ture and atmospheric pressure, reusable for seven cycles, }\end{array}$ \\
\hline $\begin{array}{l}\text { Sahoo et al. [84] } \\
\text { India }\end{array}$ & $\begin{array}{l}\text { Trimetallic porous } \\
\text { nanoparticles of } \\
\text { Au@Pd@Ru }\end{array}$ & $\begin{array}{l}\text { Facile ambient temperature } \\
\text { one-pot synthesis }\end{array}$ & $\begin{array}{l}\text { Efficient p-nitrophenol } \\
\text { reduction and degradation } \\
\text { of reactive black (RB-5) and } \\
\text { reactive red (RR-120) }\end{array}$ & $\begin{array}{l}\text { Color removal and elimination of produced amine from } \\
\text { wastewater }\end{array}$ \\
\hline $\begin{array}{l}\text { Nasrollahzadeh et al. } \\
\qquad \begin{array}{c}\text { [85] } \\
\text { Iran }\end{array}\end{array}$ & PdNPs@Zeo & $\begin{array}{l}\text { Immobilization of structur- } \\
\text { ally defined furfural with } \\
\text { 3-aminopropyltriethoxysi- } \\
\text { lane long tail, multi-step } \\
\text { organic amine function- } \\
\text { alization }\end{array}$ & $\begin{array}{c}\text { Reduction of Nigrosin } \\
\text { (NS), MB, RhB, 4-NP, } \\
\text { 2,4-dinitrophenylhydrazine } \\
(2,4-\mathrm{DNPH}), \text { potassium hex- } \\
\text { acyanoferrate }(\mathrm{III}) \mathrm{Cr}(\mathrm{VI}) \\
\text { and }(\mathrm{K} 3[\mathrm{Fe}(\mathrm{CN}) 6]),\end{array}$ & $\begin{array}{l}\text { Highly active, recoverable, and reusable for eight times at } \\
\text { room temperature, antibacterial activity against E. coli. }\end{array}$ \\
\hline $\begin{array}{l}\text { Yan et al. [86] } \\
\text { China }\end{array}$ & $\begin{array}{c}\text { Nanomultipods of } \\
\text { bimetallic PtRh-AN- } \\
\text { MPs in OAM } \\
\text { by adopting the } \\
\text { co-structure-direct- } \\
\text { ing agents of cetyl- } \\
\text { trimethylammonium } \\
\text { chloride (CTAC) and } \\
\text { creatinine }\end{array}$ & $\begin{array}{l}\text { A facile one-pot solvother- } \\
\text { mal method }\end{array}$ & $\begin{array}{l}\mathrm{RhB} \sim 97 \% \text { and } 4-\mathrm{NP} \sim 94 \% \\
\text { reduction by } \mathrm{NaBH} 4\end{array}$ & $\begin{array}{l}\text { Highly effective for RhB and 4-NP reduction than com- } \\
\text { mercial Pt black under similar conditions, recyclable }\end{array}$ \\
\hline $\begin{array}{l}\text { Mohammadi et al. [103] } \\
\text { Iran }\end{array}$ & $\begin{array}{l}\mathrm{Fe}_{3} \mathrm{O}_{4} / \mathrm{SBA}-16-\mathrm{Cit}- \\
\text { Cya-Au nanocom- } \\
\text { posite }\end{array}$ & Chemical deposition & $\begin{array}{l}\text { Reduction of MB and MO, } \\
\text { the reaction mixture turned } \\
\text { colorless. }\end{array}$ & Sustainable and highly efficient after eight cycles. \\
\hline $\begin{array}{l}\text { Memar et al. [104] } \\
\text { Iran }\end{array}$ & $\mathrm{CuO} / \mathrm{CuZnO}$ & Chemical deposition & Degradation of MO and MB & $\begin{array}{l}\text { Excellent catalytic activity and high repeatability after the } \\
\text { fifth cycle of degradation reaction. }\end{array}$ \\
\hline
\end{tabular}

showed that the polyelectrolyte brush-based catalyst had better catalytic efficiency than the one stabilized by microgel, which may be linked with the various diffusional barriers present in such stabilizing processes. A bottlebrush polymer tightly linked on a solid core of PS was also investigated as an Ag nanoparticle carrier platform. However, the synthesis method is complicated, which can lead to high costs and difficulties in raw materials personnel, and time, restricting broad realistic implementations [113, 114].

Using electrostatic attraction, a microgel of polymethacrylic acid was applied as a carrier device to accumulate the metal ions, which were then reduced to the resulting metal nanoparticles [115]. Moreover, a modified cryogel of poly(4-vinyl pyridine) was applied to adsorb metal ions and reduction treatment for the production of a compound catalyst for 4NP and MB dye reduction [116]. Besides, amidodiol was used as a reducing agent and a cross-linking agent to adsorb Ag nanoparticles in a poly(acrylic acid)-based hydrogel fibrillar system [117]. The cationic dyes such as crystal violet, $\mathrm{MB}$, and R6G were catalytically reduced with the synthesized hydrogel immobilized $\mathrm{Ag}$ nanoparticles. Temperature and $\mathrm{pH}$ were observed to have a remarkable influence on the catalyzed process. To prepare the Au and Ag nanoparticles, gel beads of calcium alginate (CA) were applied as stabilizing and reducing agents [118]. The researchers hypothesized that metallic Ag might be a superior catalyst compared to $\mathrm{Au}$ throughout this catalytic reduction process because the as-synthesized CA-stabilized nanocatalyst of $\mathrm{Ag}$ has been more effective for transforming of $4 \mathrm{NP}$ to $4 \mathrm{AP}$ compared to the $\mathrm{Au}$ equivalent. Also, the volume of $\mathrm{Ag}$ nanoparticles loaded on alginate or the surface covering with Ag nanoparticles was assumed to be more desirable for the catalyzed process than Au nanoparticles [109].

Metal catalysts could also benefit from the use of polymer dendrimers as stabilization systems. As an example, poly (amidoamine) (PAMAM) and poly (propylene imine) (PPI) dendrimers were applied to stabilize nanoparticles of $\mathrm{Au}$ for the reduction of $4 \mathrm{NP}[119,120]$. The results showed that as the dendrimer concentration increased, the rate constants of catalytic reduction for all of the processes studied declined. PPI and PAMAM dendrimers with amino groups on their surfaces were analyzed for synthesis and stabilization of Au compound nanocatalysts via laser irradiation reduction rather than chemical reduction [121]. With increasing the irradiation time, the mean size of the Au nanoparticles declined. According to the previous report, the dendrimers were adsorbed on the surfaces of NPs as a monolayer, lowering the efficiency of the catalytic performance. Furthermore, a layer-by-layer nanoreactor film was fabricated for holding silver nanoparticles utilizing a PAMAM dendrimer with positive charge and negatively charged polyacrylic acid or polystyrene sulfonate [122].

Polyacrylonitrile (PAN) substrate was also applied to embed silver nanoparticles by immobilizing the Ag nanoparticles within the polymer matrix. However, because of the blocking influence of the polymer matrix, nanoparticles of PAN/Ag matrix are inappropriate for catalytic applications. In addition, Ag nanoparticles were applied to the PAN nanofiber surface to expose most of their surface [123]. The nanofiber of PAN had been pre-modified for binding site incorporation before applying Ag nanoparticles upon its surface. Hydroxylamine hydrochloride 
Table 3.

Nanocatalysts based on organic polymer-supported metal catalysts for the degradation of pollutants in wastewater

\begin{tabular}{|c|c|c|c|c|}
\hline Authors/Country & Nanocatalysts & Synthesis method & $\begin{array}{l}\text { Application: \% removal/ } \\
\text { reduction }\end{array}$ & Catalytic behavior \\
\hline $\begin{array}{l}\text { Kaliraji et al. [131] } \\
\text { Korea }\end{array}$ & $\mathrm{ZnO}$ nano-flowers & Green synthesis & $\begin{array}{l}\text { Removal of Eosin Y (EY), } \\
\text { Malachite green (MG), and } \\
\qquad \text { MB } \sim 99 \%\end{array}$ & $\begin{array}{c}\text { High efficiency and reusability after five cycles } \\
\text { without any remarkable loss in degradation } \\
\text { performance. }\end{array}$ \\
\hline $\begin{array}{l}\text { Duan et al. }[81] \\
\text { China }\end{array}$ & $\begin{array}{l}\text { AgNPs@MOF-199s/ } \\
\text { CCFs }\end{array}$ & $\begin{array}{l}\text { Ag nanoparticles immobilized } \\
\text { on a Cu-based metal-organic } \\
\text { framework (MOF-199s) } \\
\text { supported by CCFs (car- } \\
\text { boxymethylated cellulose } \\
\text { fibers) }\end{array}$ & $\begin{array}{l}\text { The 4-nitrophenol reduction } \\
\text { to 4-aminophenol } \sim 95 \%\end{array}$ & $\begin{array}{l}\text { Better dispersion improved the catalytic activ- } \\
\text { ity; cellulose fiber increased sustainability and } \\
\text { reusability of }>91 \% \text { after five cycles. }\end{array}$ \\
\hline $\begin{array}{l}\text { M. Ajmal et al. [116] } \\
\text { Saudi Arabia }\end{array}$ & $\begin{array}{l}\text { A microgel of poly- } \\
\text { methacrylic acid }\end{array}$ & $\begin{array}{l}\text { Inverse suspension polym- } \\
\text { erization }\end{array}$ & $\begin{array}{l}\text { Absorb and reduce metal } \\
\quad \text { ions } \sim 100 \%\end{array}$ & $\begin{array}{l}\text { A carrier system that uses electrostatic interac- } \\
\text { tions to adsorb metal ions and then reduces the } \\
\text { adsorbed metal ions to metal nanoparticles }\end{array}$ \\
\hline $\begin{array}{l}\text { Bhat et al. [129] } \\
\text { Malaysia }\end{array}$ & $\begin{array}{l}\text { The Pd catalyst based } \\
\text { on the framework of } \\
\text { chitosan-tannin (CT) }\end{array}$ & $\begin{array}{l}\text { Glutaraldehyde chitosan } \\
\text { crosslinking }\end{array}$ & $\begin{array}{l}\text { The reduction of Congo } \\
\text { red } 23 \% \text { and nitrate } 71 \% \\
\text { in the absence and presence } \\
\text { of } \mathrm{H} 2 \text {. }\end{array}$ & $\begin{array}{l}\text { Catalyst is considerably thermally-stable com- } \\
\text { pared to CT support }\end{array}$ \\
\hline $\begin{array}{l}\text { Samai et al. [130] } \\
\text { India }\end{array}$ & $\begin{array}{l}\text { Nanocomposite of } \\
\text { polyaniline/cerium } \\
\text { oxide }\end{array}$ & Hydrothermal method. & $\begin{array}{l}\text { The removal of } \mathrm{RhB} \sim 91 \% \text { in } \\
\text { wastewater under irradiation } \\
\text { of the UV light. }\end{array}$ & $\begin{array}{l}\text { Polyaniline polymer was employed as active } \\
\text { catalyst support to enhance the cerium oxide } \\
\text { nanoparticle photocatalytic activity. }\end{array}$ \\
\hline $\begin{array}{l}\text { Nasrollahzadeh et al. [132] } \\
\text { Iran }\end{array}$ & $\begin{array}{l}\mathrm{Pd} / \text { reduced graphene } \\
\text { oxide (RGO) nanocom- } \\
\text { posite }\end{array}$ & Chemical deposition & $\begin{array}{c}\text { Degradation of } \mathrm{Cr}(\mathrm{VI}), \\
\text { 4-NP, } \mathrm{CR}, \mathrm{MB} \text {, and } \mathrm{MO} \text {, the } \\
\text { disappearance of absorbance } \\
\text { peaks }\end{array}$ & $\begin{array}{c}\text { Reusability and recyclability after multiple } \\
\text { employment with no alteration in catalytic } \\
\text { performance. }\end{array}$ \\
\hline $\begin{array}{l}\text { Peng et al. [133] } \\
\text { China }\end{array}$ & $\begin{array}{l}\text { Pd truncated octahe- } \\
\text { drons (PdTOs) and } \\
\text { Pd NPs }\end{array}$ & Biosynthesis & Excellent reduction of 4-NP & $\begin{array}{l}\text { The apparent rate constant }(\mathrm{Ka}) \text { over PdTOs } \\
\text { was } 0.358 \mathrm{~min}^{-1} \text { in p-NP reduction, which is } \\
\text { improved compared to spherical PdNPs-0 } \\
\qquad\left(0.08 \mathrm{~min}^{-1}\right)\end{array}$ \\
\hline $\begin{array}{l}\text { Gu et al. [77] } \\
\text { China }\end{array}$ & $\begin{array}{l}\mathrm{Pd}, \mathrm{Pt} \text {, and Ag mono- } \\
\text { metallic NPs supported } \\
\text { on graphene/ZnO }\end{array}$ & Photochemical synthesis & Electrocatalysts for $\mathrm{H}_{2} \mathrm{O}_{2}$ & Distinct electrocatalytic activity \\
\hline $\begin{array}{l}\text { Bao et al. [82]ÿ } \\
\text { China }\end{array}$ & $\mathrm{Pd} 3 \mathrm{Ag} 1 / \mathrm{GO}-\mathrm{NH}_{2}$ & One-pot method & $\begin{array}{l}\text { Excellent catalytic reduction } \\
\text { of } \mathrm{Cr}(\mathrm{VI})\end{array}$ & $\begin{array}{l}\text { Formic acid (a } \mathrm{H} 2 \text { source) at room temperature, } \\
\text { reduction rate constant was higher compared to } \\
\text { the monometallic } \mathrm{Pd}_{3} \mathrm{Ag} 1 / \mathrm{GO} \text { and } \mathrm{Pd} / \mathrm{GO}-\mathrm{NH}_{2} \text {. }\end{array}$ \\
\hline $\begin{array}{l}\text { Sahiner et al. } \\
\qquad \text { [117] } \\
\text { Saudi Arabia }\end{array}$ & $\begin{array}{l}\text { Modifiable Poly(4-vi- } \\
\text { nylpyridine) }(\mathrm{p}(4-\mathrm{VP})) \\
\text { cryogels }\end{array}$ & $\begin{array}{l}\text { Cryogellation using free radi- } \\
\text { cal polymerization method }\end{array}$ & $\begin{array}{l}\text { Complete degradation of } \\
\text { MB dye and reduction of } \\
4 \mathrm{NP}\end{array}$ & $\begin{array}{l}\text { The cryogel embedded with } \mathrm{Fe}, \mathrm{Cu}, \mathrm{Ni} \text {, and } \mathrm{Co} \\
\text { nanoparticles employed in an aqueous solution } \\
\text { with } \mathrm{NaBH}_{4}\end{array}$ \\
\hline $\begin{array}{l}\text { Narayanan }[118] \\
\text { India }\end{array}$ & $\begin{array}{c}\text { Polyacrylic acid- } \\
\text { amidodiol hydrogels } \\
\text { (SPAGs) entrapped Ag } \\
\text { nanoparticle }\end{array}$ & $\begin{array}{l}\text { Acrylic acid in situ polym- } \\
\text { erization and silver nitrate } \\
\text { reduction utilizing amidodiol } \\
\text { as cross-linking agent }\end{array}$ & $\begin{array}{l}\text { Complete reduction of crys- } \\
\text { tal violet, } \mathrm{MB} \text {, and } \mathrm{R} 6 \mathrm{G}\end{array}$ & $\begin{array}{c}\text { Temperature and } \mathrm{pH} \text { had a remarkable influence } \\
\text { on the catalytic reaction, easy separation, } \\
\text { promising reusability, and absence of induction } \\
\text { period. }\end{array}$ \\
\hline
\end{tabular}

has been utilized as a modifier by reacting with the $-\mathrm{CN}$ groups existing in PAN to create numerous amine as well as hydroxyl groups that could chelate $\mathrm{Ag}$ ions and immobilize them. Reduction treatment was used to build the Ag-decorated catalyst on the modified PAN fiber. A poly- $(3,4)$ ethylene dioxythiophene (PEDOT) substrate was also used as a support base for Pd nanoparticles. [124]. The sodium polystyrene sulfonate (NaPSS) catalytic reduction of the PEDOT supported nanoparticles of Pd in the solution was employed to improve the distribution of the PEDOT supported nanoparticles of Pd. The destructive impact on the catalyzed process must be considered because the surfactant Na-PSS is inclined to position the $\mathrm{Pd}$ catalyst. To stabilize $\mathrm{Au}$ and $\mathrm{Fe}_{3} \mathrm{O}_{4}$ nanoparticles, the conducting polymer polypyrrole (PPy) was utilized [125]. However, these nanoparticles were wrapped or embedded in a polymer substrate, creating a great diffusion barrier to the catalyst impairing MB dye catalytic activity. The carrier platform for the Au nanocatalyst [126] was
Poly(allylamine hydrochloride) which was modified with composite sub microspheres poly(glycidyl methacrylate). The results showed that the carrier system's positive charges and epoxy groups could improve the catalyzed process. Epoxy groups have a role as electron acceptors because of their electrophilicity; therefore, they capture electrons and create an electron-rich region at the Au nanoparticle-sphere interface. This area could represent an electron reservoir, allowing the electron to be transferred to the reactant 4-NP in catalytic reduction of 4-NP; in the meantime, 4-NP anions could be adsorbed onto the positively charged surfaces of the sphere with ionic attraction. Aside from the multistep procedures and complex preparing requirements that restrict wide implementations, the composite sphere catalyst's reusability and stability have not been studied. Furthermore, the electrons captured by epoxy groups may not be freed, and the reduction of the epoxy groups could occur in the catalyzed reduction process by the captured electrons [1]. 


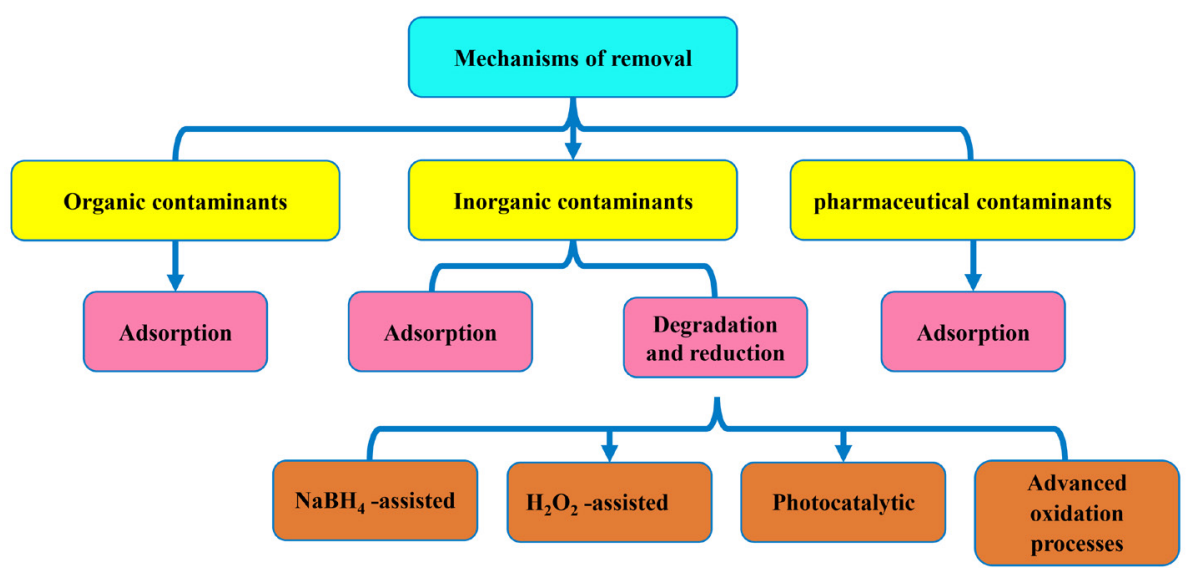

Fig. 4. Removal mechanisms by nanomaterials for different pollutants.

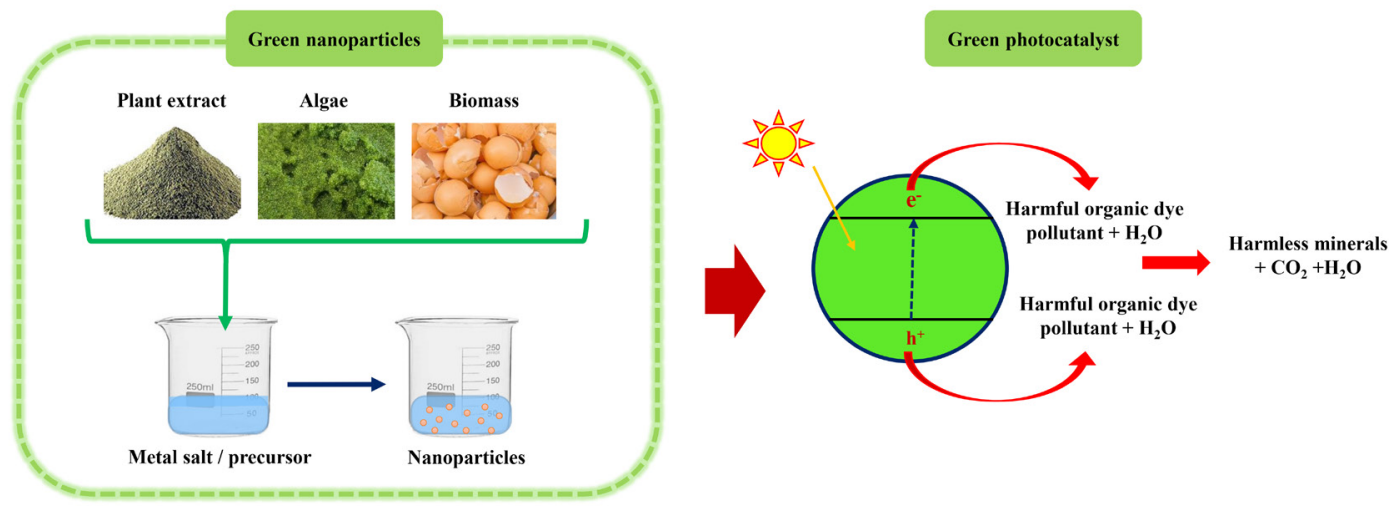

Fig. 5. Mechanism of dye photocatalytic degradation via green-synthesized nanoparticles.

To stabilize Au nanoparticles for the 4-NP reduction catalysis, quaternary ammonium resin beads of PS were used. The results showed that the tinier the Au nanoparticles, the quicker the catalyzed process. The Au nanoparticles immobilized on the surface of resin seem fragile because they could be dissociated with cationic surfactants, suggesting the composite catalyst's low endurance [127]. Bhat et al. [128] synthesized a Pd catalyst established on the chitosan-tannin (CT) framework. The catalyst's catalytic efficiency was investigated in the presence and absence of $\mathrm{H}_{2}$ to reduce Congo red and nitrate. Within 60 and $20 \mathrm{~min}$ utes, respectively, the catalytic performances eliminated 23 percent and 71 percent of Congo red and nitrate.

Samai et al. [129] used a conducting polymer of polyaniline as active catalyst support to promote the cerium oxide nanoparticle photocatalytic activity. The as-prepared nanocomposite of polyaniline/cerium oxide shows significantly improved photocatalytic efficiency than some oxide nanoparticles or polyaniline for removing $\mathrm{RhB}$ in wastewater under the UV light irradiation. The results indicated that a nanocomposite containing cerium oxide nanoparticles and polyaniline in a 1:1 molar ratio degraded 91 percent of Rhodamine B in 2 hours, while cerium oxide nanoparticles only degraded $10 \%$. Recent studies on applying various organic polymer-supported metal nanocatalysts for pollutant removal from wastewater are summarized in Table 3.

\section{Catalytic mechanisms}

Different types of biological, chemical, and physical technologies such as advanced oxidation processes (AOPs), ultra-filtration, membrane, sedimentation, flocculation, adsorption, oxidation, reverse osmo- sis, and ion-exchange are employed for treating wastewater. Because of their excellent performance, good reproducibility, convenience, and ease of handling, AOPs including photocatalysis, Fenton reaction, ozonation, or their variations are used to remove organic contaminants [134].

AOP is classified as remarkably nonselective and reactive chemical oxidants, including $\bullet \mathrm{O}_{2}, \mathrm{O}_{3}, \mathrm{H}_{2} \mathrm{O}_{2}$, and $\bullet \mathrm{OH}$ to remove resistant and non-biodegradable organic pollutants.

As shown below, the Fenton reaction by radical of $\bullet \mathrm{OH}$ is a low-cost, efficient, and sustainable wastewater treatment process. [135]:

$\mathrm{Fe}^{2+}+\mathrm{H}_{2} \mathrm{O}_{2}+\mathrm{H}^{+} \rightarrow \mathrm{Fe}^{3+}+\cdot \mathrm{OH}+\mathrm{H}_{2} \mathrm{O}$

Jaafar et al. [136] have studied some quantum calculations based on the ELF (electron localization function) and DFT (density functional theory) to investigate the removal process of Neutral Red dye (NR) in sewerage. In an aqueous medium, the Fenton reaction mechanism between free radicals $(\bullet \mathrm{OH})$ and the NR dye for its degradation was examined. For eliminating organic and inorganic pollutants and eradication of toxins (Fig. 4) from wastewater, freshwater sediments, groundwater, and other sites, a variety of pathways have been used, including reduction and (photo)degradation, adsorption, and UV photolysis/photocatalysis [137].

Nanomaterials can adsorb or degrade the contaminants using several catalytic approaches, including photocatalysis, $\mathrm{H}_{2} \mathrm{O}_{2}$, and $\mathrm{NaBH}_{4}$, whereas green-synthesized nanoparticles are an excellent choice for photocatalytic wastewater treatment (Fig. 5) [138]. Toxic organic pollutants are broken down into other materials [139] or fully mineralized components, producing water, carbon dioxide, or other inorganic ions. In general, a semiconductor such as $\mathrm{TiO}_{2}$ is capable of absorbing light with a wavelength equal to or greater than the wavelength of the semi- 
conductor bandgap, resulting in the creation of electron-hole $\left(\mathrm{e}^{-}-\mathrm{h}^{+}\right)$ pairs [140, 141]. Reduction-oxidation reactions involve the interaction of nanocatalyst with adsorbate molecules. As shown in the equations below, $\mathrm{h}_{\mathrm{vb}}^{+}$interacts with surface-bound water to form $\bullet \mathrm{OH}$, and oxygen selects e-CB to form a superoxide radical anion.

New green prepared metal-organic framework-based photocatalytic materials have recently received a great deal of interest, particularly because of their capacity for environmentally friendly removal of toxic organic contaminants. [142-144]. Several studies have reported on the use of transition metals in MOF-based photocatalysts to remove extremely toxic contaminants under UV/vis, UV, and visible light. First, a MOF-5 was utilized to act as an efficient photocatalyst [145, 146]; these MOFs have a wide absorption band in the $500-840 \mathrm{~nm}$ range, which is related to the delocalized electron that lives on a time scale of microsecond and is most probably occupies a conduction band, with a value of conduction band energy equal to $0.2 \mathrm{~V}$ vs. NHE and a $3.4 \mathrm{eV}$ bandgap. For the degradation of aqueous phenol, this method showed proportional performance with $\mathrm{TiO}_{2}$ or $\mathrm{ZnO}$. MOF-5 is an efficient photocatalyst since it is in a charge-separated state, with holes in the valence bands and electrons in the conduction band. As a result, phenol photodegradation can be accomplished by a series of reactions, including the primary formation of radical cations through transferring a phenol electron to the MOF-5 hole, or the oxygen active specie formation, including superoxide radical anions, by the interaction between photo-ejected electrons and oxygen. [147, 148]. Das et al. [149] prepared a double interpenetrated porous MOF (UTSA-38) containing $\mathrm{Zn}_{4} \mathrm{O}$ with a bandgap of $2.85 \mathrm{eV}$, and its photocatalytic performance for the removal of $\mathrm{MO}$ in aqueous systems under UV/vis, visible light, as well as dark conditions was shown to be strong. According to the findings, under UV light for 120 minutes, methyl orange could be decayed into colorless smaller particles.

In reducing poisonous nitro compounds to useful and valuable amino compounds in aqueous systems, $\mathrm{NaBH}_{4}$ has attracted much attention as a preferred alternative to hydrogen sources and a water-soluble reductant. Because metal hydride structures formed from $\mathrm{BH}_{4}$-ions through $\pi-\pi$ stacking interaction have been evaluated as intermediates in this reduction reaction, the activation of $\mathrm{NaBH}_{4}$ is a major procedure that needs to take a metal material as the active site. The existence of a nanocatalyst of Pd stabilized amine-modified zeolite (Pd NPs@Zeo) with stacking interactions of $\pi-\pi$ was found to explain the reduction of toxic 4-NP by $\mathrm{NaBH}_{4}$ reductant [84]. Pd NPs@Zeo transform $\mathrm{NaBH}_{4}$ to molecular $\mathrm{H}_{2}$ and $\mathrm{BO}_{2}$ dissociated on the nanocatalyst's surface, and the adsorbed 4-NP interacts with the dissociated $\mathrm{H}_{2}$ gas to produce 4-aminophenol. Consequently, the as-synthesized aminophenol is eventually desorbed from the nanocatalyst base, resuming the catalytic process. The nanocatalyst also plays a part in facilitating simple reduction by adsorbing molecular $\mathrm{H}_{2}$ or 4-NP nearby. Magnetically separable nano-bio hybrid catalysts, $\mathrm{Fe}_{3} \mathrm{O}_{4} @ \mathrm{Ch}-\mathrm{PdNPs}$ and $\mathrm{Fe}_{3} \mathrm{O}_{4} @ \mathrm{Ch}$-AuNPs, have been prepared and designed by a three-step procedure according to the process of biosynthetic mineralization [150]. Shewanella algae produced spherical $\mathrm{Fe}_{3} \mathrm{O}_{4}$ nanoparticles $(35 \mathrm{~nm}$ ) that were then coated or functionalized with chitosan, accompanied by modification with nanoparticles of Pd or Au to produce a reusable and water-dispersible nano-bio hybrid catalyst that showed significant functionality for 4-NP reduction and dye photodegradation ( $>99$ percent) in contaminated water at ambient temperatures $\left(25^{\circ} \mathrm{C}\right)[151]$.

This reaction was triggered by the adsorbent and reduction of methylene blue by $\mathrm{Au}$ or Pd nanoparticles via the electron transfer process. The reaction rates exhibited pseudo-second-order rate kinetics; under UV light, the $\mathrm{Fe}_{3} \mathrm{O}_{4} @ \mathrm{Ch}-\mathrm{Pd}$ and $\mathrm{Au}$ nanoparticles finished the methylene blue reduction in just 1 minute, with apparent rate constants $\left(\mathrm{k}_{\text {app }}\right)$ of $5.0 \mathrm{~min}^{-1}$ and $4.0 \mathrm{~min}^{-1}$, respectively. Furthermore, the normalized rate constant $\left(\mathrm{k}_{\mathrm{nor}}\right)$ values of the nanoparticles of $\mathrm{Au}$ and $\mathrm{Fe}_{3} \mathrm{O}_{4} @ \mathrm{Ch}-\mathrm{Pd}$ for the degradation of methylene blue are $1.14 \times 10^{2}$ and $1.72 \times 10^{2} \mathrm{mmol}^{-1} \mathrm{~s}^{-1}$, respectively, showing catalytic activities of the nanoparticles of $\mathrm{Au}$ and $\mathrm{Fe}_{3} \mathrm{O}_{4} @ \mathrm{Ch}-\mathrm{Pd}$. For eliminating severely carcinogenic and toxic arsenic (As), green-fabricated amorphous nanoparticles of Fe with $51 \mathrm{~m}^{2} \mathrm{~g}^{-1}$ Brunauer-Emmett-Teller (BET) area were employed [150].

Arsenate was reported to be evenly adsorbed on the surfaces of $\mathrm{Fe}$ nanoparticles; Fourier-transform infrared spectroscopy (FTIR) spectrometer analysis revealed that the adsorption was mainly due to a FeOAs bond, but X-ray photoelectron spectroscopy (XPS) findings show that only As(V) was adsorbed. Therefore, this method for eliminating arsenate relies on $\mathrm{Fe}$ nanoparticles interacting with arsenate to generate a monodentate chelating ligand, and then followed by a complex of bidentate binuclear. More studies showed that the synthesized nanoparticles' maximum arsenate adsorbent potential was about $14.6 \mathrm{mg} \mathrm{g}^{-1}$ and that the optimum range of $\mathrm{pH}$ for anionic arsenate adsorbent was around 4 to 6. [150]. The Langmuir adsorption isotherms showed that adsorption of $\mathrm{As}(\mathrm{V})$ by Fe nanoparticles matched their regression coefficient $\left(\mathrm{R}^{2}\right.$ $=0.99$ ), confirming the suggested chemisorption; the adsorption yield matched the pseudo-second-order kinetic model favorably. As a result, the green synthesis of $\mathrm{Fe}$ nanoparticles is a promising option for removing arsenic while also being simple to synthesize.

\section{Conclusions and future insights}

This work focuses on organic polymer-supported metal catalysts, noble metals nanocatalysts, and magnetic nanocatalysts and then summarizes their mechanism in treating industrial effluent. Studies show the efficacy and promising application of these nanocatalysts for the removal of industrial effluents. Since low-cost preparation is critical for their uses in wastewater treatment, future research could focus on measurement of interactive mechanisms in the water treatment system of these nanomaterials and refining their economic viability. In addition, the toxicity of these nanomaterials for the environment and human health should be examined and (quali-quantitative) risk assessment evaluations are suggested in this regard. To ensure that their implementation is safe, general assessments of their harm are needed. More studies are required to compare the nanomaterials' relative performances to recognize favorable earth-abundant materials, resource utilization, and energy usage.

Some essential future perspectives should be considered for biogenic nanomaterials deployment for water purification and treatment. Comprehensive research is needed before these green-synthesized nanomaterials and nanocatalysts can be used on a commercial or industrial scale. Since these nanomaterials may result in secondary contamination, this critical problem must be thoroughly investigated. While the preparation of these nanomaterials is eco-friendly and simple, some challenging and essential factors, such as stability issues and the influence of reaction parameters, should be optimized and analyzed, as these factors can improve their pollutant removal activity, morphologies, and behavior of nanomaterials. Moreover, the extraction and purification of the synthesized biogenic nanomaterials are essential for additional applications. They should also be isolated as pure as possible for wastewater treatment. More studies are needed to find nanomaterials of multifunctional and innovative nanohybrids to improve their efficient utility. The cost-effectiveness of green-synthesized nanomaterials versus nanoparticles synthesized using traditional methods should be investigated. The assessment of restorative quality and efficacy issues is conducted in laboratory settings, simulating the parameter ranges of actual environmental levels, but it's vital to examine and analyze the outcomes from real-world scenarios.

\section{Conflict of interest}

The authors declare that there is no conflict of interest that would prejudice the impartiality of this scientific work. 


\section{REFERENCES}

[1] H. Hu, J.H. Xin, H. Hu, X. Wang, D. Miao, Y. Liu, Synthesis and stabilization of metal nanocatalysts for reduction reactions-a review, Journal of materials chemistry A 3(21) (2015) 11157-11182.

[2] M. Kamranifar, T.J. Al-Musawi, M. Amarzadeh, A. Hosseinzadeh, N. Nasseh, M. Qutob, F.S. Arghavan, Quick adsorption followed by lengthy photodegradation using $\mathrm{FeNi}_{3} @ \mathrm{SiO}_{2} @ \mathrm{ZnO}$ : A promising method for complete removal of penicillin G from wastewater, Journal of Water Process Engineering 40 (2021) 101940. [3] A. Tkaczyk, K. Mitrowska, A. Posyniak, Synthetic organic dyes as contaminants of the aquatic environment and their implications for ecosystems: a review, Science of The Total Environment 717 (2020) 137222.

[4] C.G. Awuchi, H. Twinomuhwezi, C.G. Awuchi, V.S. Igwe, I.O. Amagwula, Industrial Waste Management, Treatment, and Health Issues: Wastewater, Solid, and Electronic Wastes, European Academic Research 8(2) (2020) 1081-1119.

[5] M. de Oliveira, B.E.F. Frihling, J. Velasques, F.J.C. Magalhães Filho, P.S. Cavalheri, L. Migliolo, Pharmaceuticals residues and xenobiotics contaminants: occurrence, analytical techniques and sustainable alternatives for wastewater treatment, Science of The Total Environment 705 (2020) 135568.

[6] B.K. Ghosh, S. Hazra, B. Naik, N.N. Ghosh, Preparation of Cu nanoparticle loaded SBA-15 and their excellent catalytic activity in reduction of variety of dyes, Powder Technology 269 (2015) 371-378.

[7] D. Kim, H. Kim, J.Y. Chang, Designing internal hierarchical porous networks in polymer monoliths that exhibit rapid removal and photocatalytic degradation of aromatic pollutants, Small 16(22) (2020) 1907555.

[8] P.T. Anastas, J.C. Warner, Principles of green chemistry, Green chemistry: Theory and practice (1998) 29-56.

[9] G.E. Crisenza, P. Melchiorre, Chemistry glows green with photoredox catalysis, Nature communications 11(1) (2020) 1-4.

[10] Y. Ren, Y. Ma, G. Min, W. Zhang, L. Lv, W. Zhang, A mini review of multifunctional ultrafiltration membranes for wastewater decontamination: Additional functions of adsorption and catalytic oxidation, Science of The Total Environment (2020) 143083

[11] T.-L. Chen, H. Kim, S.-Y. Pan, P.-C. Tseng, Y.-P. Lin, P.-C. Chiang, Implementation of green chemistry principles in circular economy system towards sustainable development goals: Challenges and perspectives, Science of the Total Environment 716 (2020) 136998.

[12] C.-H.C. Zhou, J.N. Beltramini, Y.-X. Fan, G.M. Lu, Chemoselective catalytic conversion of glycerol as a biorenewable source to valuable commodity chemicals, Chemical Society Reviews 37(3) (2008) 527-549.

[13] V. Polshettiwar, R.S. Varma, Green chemistry by nano-catalysis, Green Chemistry $12(5)$ (2010) 743-754.

[14] M.B. Gawande, P.S. Branco, R.S. Varma, Nano-magnetite $\left(\mathrm{Fe}_{3} \mathrm{O}_{4}\right)$ as a support for recyclable catalysts in the development of sustainable methodologies, Chemical Society Reviews 42(8) (2013) 3371-3393.

[15] L. Bazli, A. Khavandi, M.A. Boutorabi, M. Karrabi, Morphology and viscoelastic behavior of silicone rubber/EPDM/Cloisite 15A nanocomposites based on Maxwell model, Iranian Polymer Journal 25(11) (2016) 907-918.

[16] L. Bazli, A. Khavandi, M.A. Boutorabi, M. Karrabi, Correlation between viscoelastic behavior and morphology of nanocomposites based on SR/EPDM blends compatibilized by maleic anhydride, Polymer 113 (2017) 156-166.

[17] N. Manojkumar, C. Muthukumaran, G. Sharmila, A. Aishwarya, Heterogeneous nanocatalysts for sustainable biodiesel production: A review, Journal of Environmental Chemical Engineering (2020) 104876.

[18] M. Shokouhimehr, Magnetically separable and sustainable nanostructured catalysts for heterogeneous reduction of nitroaromatics, Catalysts 5(2) (2015) 534560.

[19] S. Tripathi, W. Boggs, Role of Nanocatalysts in Synthesis of Carbon Nanofiber, Carbon Nanofibers: Fundamentals and Applications (2021) 49.

[20] R. Naveenkumar, G. Baskar, Process optimization, green chemistry balance and technoeconomic analysis of biodiesel production from castor oil using heterogeneous nanocatalyst, Bioresource Technology 320 (2021) 124347.

[21] S.B. Singh, P.K. Tandon, Catalysis: a brief review on nano-catalyst, J Energy Chem Eng 2(3) (2014) 106-115.

[22] S. Kazemifard, H. Nayebzadeh, N. Saghatoleslami, E. Safakish, Application of magnetic alumina-ferric oxide nanocatalyst supported by $\mathrm{KOH}$ for in-situ transesterification of microalgae cultivated in wastewater medium, Biomass and Bioenergy 129 (2019) 105338.

[23] A. Marjani, M.H. Zare, M.H. Sadeghi, S. Shirazian, M. Ghadiri, Synthesis of alginate-coated magnetic nanocatalyst containing high-performance integrated enzyme for phenol removal, Journal of Environmental Chemical Engineering (2020) 104884 .
[24] F. Sadegh, N. Politakos, E.G. de San Román, O. Sanz, I. Perez-Miqueo, S.E. Moya, R. Tomovska, A green synthesis of nanocatalysts based on reduced graphene oxide/magnetic nanoparticles for the degradation of Acid Red 1, RSC Advances 10(64) (2020) 38805-38817.

[25] A.S. Ethiraj, P. Uttam, K. Varunkumar, K.F. Chong, G.A. Ali, Photocatalytic performance of a novel semiconductor nanocatalyst: Copper doped nickel oxide for phenol degradation, Materials Chemistry and Physics 242 (2020) 122520.

[26] G.A. Ali, Photocatalytic performance of a novel semiconductor nanocatalyst: Copper doped nickel oxide for phenol degradation, (2019).

[27] T. Jayabalan, S. Naina Mohamed, M. Matheswaran, T. Radhakrishnan, A. Pugazhendhi, A. Alagarsamy, Enhanced biohydrogen production from sugar industry effluent using nickel oxide and cobalt oxide as cathode nanocatalysts in microbial electrolysis cell, International Journal of Energy Research (2020).

[28] A.S. Adekunle, J.A. Oyekunle, L.M. Durosinmi, O.S. Oluwafemi, D.S Olayanju, A.S. Akinola, O.R. Obisesan, O.F. Akinyele, T.A. Ajayeoba, Potential of cobalt and cobalt oxide nanoparticles as nanocatalyst towards dyes degradation in wastewater, Nano-Structures \& Nano-Objects 21 (2020) 100405.

[29] C.-O.O. Maureen, O.J. Nnaemeka, A.N. Basil, O.E. Emeka, Photocatalytic degradation of a basic dye using zinc oxide nanocatalyst, Int. Lett. Chem. Phys. Astron 81 (2019) 18-26.

[30] L. Pandian, R. Rajasekaran, P. Govindan, Synergistic effect of ozone on cadmium doped zinc oxide nanocatalyst for the degradation of textile dyeing wastewater, Materials Research Express 6(8) (2019) 085513.

[31] Q. Sun, X. Fu, R. Si, C.H. Wang, N. Yan, Mesoporous silica-encaged ultrafine bimetallic nanocatalysts for $\mathrm{CO}_{2}$ hydrogenation to formates, ChemCatChem 11(20) (2019) 5093-5097.

[32] P.C.L. Muraro, S.R. Mortari, B.S. Vizzotto, G. Chuy, C. Dos Santos, L.F.W Brum, W.L. da Silva, Iron oxide nanocatalyst with titanium and silver nanoparticles: Synthesis, characterization and photocatalytic activity on the degradation of Rhodamine B dye, Scientific reports 10(1) (2020) 1-9.

[33] Z. Cheng, X. Chu, J. Yin, B. Dai, W. Zhao, Y. Jiang, J. Xu, H. Zhong, P. Zhao, L. Zhang, Formation of composite fuels by coating aluminum powder with a cobalt nanocatalyst: Enhanced heat release and catalytic performance, Chemical Engineering Journal 385 (2020) 123859.

[34] G. Jaiswal, V.G. Landge, D. Jagadeesan, E. Balaraman, Iron-based nanocatalyst for the acceptorless dehydrogenation reactions, Nature communications $8(1)$ (2017) 1-13.

[35] K. Zhang, J.H. Cha, S.Y. Jeon, K.O. Kirlikovali, M. Ostadhassan, V. Rasouli, O.K. Farha, H.W. Jang, R.S. Varma, M. Shokouhimehr, Pd modified prussian blue frameworks: Multiple electron transfer pathways for improving catalytic activity toward hydrogenation of nitroaromatics, Molecular Catalysis 492 (2020) 110967. [36] H. Suo, L. Xu, Y. Xue, X. Qiu, H. Huang, Y. Hu, Ionic liquids-modified cellulose coated magnetic nanoparticles for enzyme immobilization: improvement of catalytic performance, Carbohydrate polymers 234 (2020) 115914.

[37] K. Yan, C. Jarvis, T. Lafleur, Y. Qiao, X. Xie, Novel synthesis of Pd nanoparticles for hydrogenation of biomass-derived platform chemicals showing enhanced catalytic performance, RSC advances 3(48) (2013) 25865-25871.

[38] K. Yan, T. Lafleur, G. Wu, J. Liao, C. Ceng, X. Xie, Highly selective production of value-added $\gamma$-valerolactone from biomass-derived levulinic acid using the robust Pd nanoparticles, Applied Catalysis A: General 468 (2013) 52-58.

[39] M. Shokouhimehr, K. Hong, T.H. Lee, C.W. Moon, S.P. Hong, K. Zhang, J.M. Suh, K.S. Choi, R.S. Varma, H.W. Jang, Magnetically retrievable nanocomposite adorned with Pd nanocatalysts: efficient reduction of nitroaromatics in aqueous media, Green Chemistry 20(16) (2018) 3809-3817.

[40] S. Luo, Z. Zeng, G. Zeng, Z. Liu, R. Xiao, M. Chen, L. Tang, W. Tang, C. Lai, M. Cheng, Metal organic frameworks as robust host of palladium nanoparticles in heterogeneous catalysis: Synthesis, application, and prospect, ACS applied materials \& interfaces 11(36) (2019) 32579-32598.

[41] M.J. Ndolomingo, N. Bingwa, R. Meijboom, Review of supported metal nanoparticles: synthesis methodologies, advantages and application as catalysts, Journal of Materials Science 55(15) (2020) 6195-6241.

[42] K. Yan, T. Lafleur, C. Jarvis, G. Wu, Clean and selective production of $\gamma$-valerolactone from biomass-derived levulinic acid catalyzed by recyclable Pd nanoparticle catalyst, Journal of cleaner production 72 (2014) 230-232.

[43] B.R. Cuenya, Synthesis and catalytic properties of metal nanoparticles: Size, shape, support, composition, and oxidation state effects, Thin Solid Films 518(12) (2010) 3127-3150.

[44] M.B. Gawande, A.K. Rathi, P.S. Branco, I.D. Nogueira, A. Velhinho, J.J. Shrikhande, U.U. Indulkar, R.V. Jayaram, C.A.A. Ghumman, N. Bundaleski, Regio-and Chemoselective Reduction of Nitroarenes and Carbonyl Compounds over Recyclable Magnetic Ferrite-Nickel Nanoparticles $\left(\mathrm{Fe}_{3} \mathrm{O}_{4} / \mathrm{Ni}\right)$ by Using Glycerol as a Hydrogen Source, Chemistry-A European Journal 18(40) (2012) 12628- 
12632 .

[45] M.B. Gawande, A. Rathi, I.D. Nogueira, C. Ghumman, N. Bundaleski, O. Teodoro, P.S. Branco, A Recyclable ferrite-Co magnetic nanocatalyst for the oxidation of alcohols to carbonyl compounds, ChemPlusChem 77(10) (2012) 865-871. [46] F. Sharifianjazi, M. Moradi, N. Parvin, A. Nemati, A.J. Rad, N. Sheysi, A. Abouchenari, A. Mohammadi, S. Karbasi, Z. Ahmadi, Magnetic $\mathrm{CoFe}_{2} \mathrm{O}_{4}$ nanoparticles doped with metal ions: a review, Ceramics International (2020).

[47] J. Feng, L. Su, Y. Ma, C. Ren, Q. Guo, X. Chen, $\mathrm{CuFe}_{2} \mathrm{O}_{4}$ magnetic nanoparticles: A simple and efficient catalyst for the reduction of nitrophenol, Chemical engineering journal 221 (2013) 16-24.

[48] Y. Li, J. Shen, Y. Hu, S. Qiu, G. Min, Z. Song, Z. Sun, C. Li, General flame approach to chainlike $\mathrm{MFe}_{2} \mathrm{O}_{4}$ spinel $(\mathrm{M}=\mathrm{Cu}, \mathrm{Ni}, \mathrm{Co}, \mathrm{Zn})$ nanoaggregates for reduction of nitroaromatic compounds, Industrial \& Engineering Chemistry Research 54(40) (2015) 9750-9757.

[49] A. Goyal, S. Bansal, S. Singhal, Facile reduction of nitrophenols: Comparative catalytic efficiency of $\mathrm{MFe}_{2} \mathrm{O}_{4}(\mathrm{M}=\mathrm{Ni}, \mathrm{Cu}, \mathrm{Zn})$ nano ferrites, International journal of hydrogen energy 39(10) (2014) 4895-4908.

[50] A. Goyal, S. Bansal, V. Kumar, J. Singh, S. Singhal, Mn substituted cobalt ferrites $\left(\mathrm{CoMnxFe}_{2-\mathrm{x}} \mathrm{O}_{4}(\mathrm{x}=0.0,0.2,0.4,0.6,0.8,1.0)\right)$ : As magnetically separable heterogeneous nanocatalyst for the reduction of nitrophenols, Applied Surface Science 324 (2015) 877-889.

[51] V.S. Kiran, S. Sumathi, Comparison of catalytic activity of bismuth substituted cobalt ferrite nanoparticles synthesized by combustion and co-precipitation method, Journal of Magnetism and Magnetic Materials 421 (2017) 113-119.

[52] C. Singh, A. Goyal, S. Singhal, Nickel-doped cobalt ferrite nanoparticles: efficient catalysts for the reduction of nitroaromatic compounds and photo-oxidative degradation of toxic dyes, Nanoscale 6(14) (2014) 7959-7970.

[53] C. Dey, A. Chaudhuri, A. Ghosh, M. Mandal Goswami, Magnetic cubeshaped $\mathrm{NiFe}_{2} \mathrm{O}_{4}$ nanoparticles: an effective model catalyst for nitro compound reduction, (2017).

[54] M. Dhiman, A. Goyal, V. Kumar, S. Singhal, Designing different morphologies of NiFe $2 \mathrm{O} 4$ for tuning of structural, optical and magnetic properties for catalytic advancements, New Journal of Chemistry 40(12) (2016) 10418-10431.

[55] I. Papadas, K. Subrahmanyam, M.G. Kanatzidis, G. Armatas, Templated assembly of BiFeO 3 nanocrystals into 3D mesoporous networks for catalytic applications, Nanoscale 7(13) (2015) 5737-5743.

[56] M. Amir, U. Kurtan, A. Baykal, Rapid color degradation of organic dyes by $\mathrm{Fe}_{3} \mathrm{O}_{4} @$ His@Ag recyclable magnetic nanocatalyst, Journal of Industrial and Engineering Chemistry 27 (2015) 347-353.

[57] U. Kurtan, M. Amir, A. Yıldız, A. Baykal, Synthesis of magnetically recyclable $\mathrm{MnFe}_{2} \mathrm{O}_{4} @ \mathrm{SiO}_{2} @ \mathrm{Ag}$ nanocatalyst: Its high catalytic performances for azo dyes and nitro compounds reduction, Applied Surface Science 376 (2016) 16-25.

[58] P. Mohammadi, H. Sheibani, Green synthesis of $\mathrm{Fe}_{3} \mathrm{O}_{4} @ \mathrm{SiO}_{2}-\mathrm{Ag}$ magnetic nanocatalyst using safflower extract and its application as recoverable catalyst for reduction of dye pollutants in water, Applied Organometallic Chemistry 32(4) (2018) e4249.

[59] H. Veisi, S. Razeghi, P. Mohammadi, S. Hemmati, Silver nanoparticles decorated on thiol-modified magnetite nanoparticles $\left(\mathrm{Fe}_{3} \mathrm{O}_{4} / \mathrm{SiO}_{2}-\mathrm{Pr}-\mathrm{S}-\mathrm{Ag}\right)$ as a recyclable nanocatalyst for degradation of organic dyes, Materials Science and Engineering: C 97 (2019) 624-631.

[60] B.K. Ghosh, D. Moitra, M. Chandel, H. Lulla, N.N. Ghosh, Ag nanoparticle immobilized mesoporous $\mathrm{TiO}_{2}$-cobalt ferrite nanocatalyst: A highly active, versatile, magnetically separable and reusable catalyst, Materials Research Bulletin 94 (2017) 361-370.

[61] M.S. Najafinejad, P. Mohammadi, M. Mehdi Afsahi, H. Sheibani, Biosynthesis of $\mathrm{Au}$ nanoparticles supported on $\mathrm{Fe}_{3} \mathrm{O}_{4} @$ polyaniline as a heterogeneous and reusable magnetic nanocatalyst for reduction of the azo dyes at ambient temperature, Materials Science and Engineering: C 98 (2019) 19-29.

[62] P.L.d. Oliveira, N.S. Lima, A.C.F.d.M. Costa, E.B. Cavalcanti, L.d.S. Conrado, Obtaining TiO2:CoFe2O4 nanocatalyst by Pechini method for diuron degradation and mineralization, Ceramics International 46(7) (2020) 9421-9435.

[63] H.H. Mohamed, N.A. Alomair, S. Akhtar, T.E. Youssef, Eco-friendly synthesized $\alpha$-Fe2O3/TiO2 heterojunction with enhanced visible light photocatalytic activity, Journal of Photochemistry and Photobiology A: Chemistry 382 (2019) 111951.

[64] R. Ranjith, V. Renganathan, S.-M. Chen, N.S. Selvan, P.S. Rajam, Green synthesis of reduced graphene oxide supported $\mathrm{TiO} 2 / \mathrm{Co} 3 \mathrm{O} 4$ nanocomposite for photocatalytic degradation of methylene blue and crystal violet, Ceramics International 45(10) (2019) 12926-12933.

[65] V. Vetere, A.B. Merlo, M.L. Casella, Chemoselective hydrogenation of aromatic ketones with Pt-based heterogeneous catalysts. Substituent effects, Applied Catalysis A: General 491 (2015) 70-77.
[66] W. Jin, L. Pastor-Pérez, J.J. Villora-Pico, M.M. Pastor-Blas, A. Sepúlveda-Escribano, S. Gu, N.D. Charisiou, K. Papageridis, M.A. Goula, T.R. Reina, Catalytic conversion of palm oil to bio-hydrogenated diesel over novel N-doped activated carbon supported Pt nanoparticles, Energies 13(1) (2020) 132.

[67] H.M.A. Sharif, A. Mahmood, H.-Y. Cheng, R. Djellabi, J. Ali, W.-L. Jiang, S.-S. Wang, M.R. Haider, N. Mahmood, A.-J. Wang, $\mathrm{Fe}_{3} \mathrm{O}_{4}$ nanoparticles coated with EDTA and Ag nanoparticles for the catalytic reduction of organic dyes from wastewater, ACS Applied Nano Materials 2 (8) (2019) 5310-5319.

[68] G.P. Sahoo, D.K. Bhui, D. Das, A. Misra, Synthesis of anisotropic gold nanoparticles and their catalytic activities of breaking azo bond in sudan-1, Journal of Molecular Liquids 198 (2014) 215-222.

[69] Z.-H. Xie, H.-Y. Zhou, C.-S. He, Z.-C. Pan, G. Yao, B. Lai, Synthesis, application and catalytic performance of layered double hydroxide based catalysts in advanced oxidation processes for wastewater decontamination: A review, Chemical Engineering Journal (2021) 128713.

[70] X.-Y. Zhang, W.-L. Yu, J. Zhao, B. Dong, C.-G. Liu, Y.-M. Chai, Recent development on self-supported transition metal-based catalysts for water electrolysis at large current density, Applied Materials Today 22 (2021) 100913.

[71] M.S. Holden, K.E. Nick, M. Hall, J.R. Milligan, Q. Chen, C.C. Perry, Synthesis and catalytic activity of pluronic stabilized silver-gold bimetallic nanoparticles, RSC advances 4(94) (2014) 52279-52288.

[72] S.G. Babu, M. Gopiraman, D. Deng, K. Wei, R. Karvembu, I.S. Kim, Robust $\mathrm{Au}-\mathrm{Ag} / \mathrm{graphene}$ bimetallic nanocatalyst for multifunctional activity with high synergism, Chemical Engineering Journal 300 (2016) 146-159.

[73] N.V. Long, M. Ohtaki, T.D. Hien, J. Randy, M. Nogami, A comparative study of Pt and Pt-Pd core-shell nanocatalysts, Electrochimica Acta 56(25) (2011) 91339143.

[74] Z. Bo, X. Guo, X. Wei, H. Yang, J. Yan, K. Cen, Density functional theory calculations of $\mathrm{NO}_{2}$ and $\mathrm{H}_{2} \mathrm{~S}$ adsorption on the group 10 transition metal (Ni, $\mathrm{Pd}$ and Pt) decorated graphene, Physica E: Low-dimensional Systems and Nanostructures 109 (2019) 156-163.

[75] K. Patel, S. Kapoor, D.P. Dave, T. Mukherjee, Synthesis of Pt, Pd, Pt/Ag and $\mathrm{Pd} / \mathrm{Ag}$ nanoparticles by microwave-polyol method, Journal of Chemical Sciences 117(4) (2005) 311-316.

[76] B.H. Susanto, J.R.V. Siallagan, Analysis of $\mathrm{NiMoP} / \gamma-\mathrm{Al}_{2} \mathrm{O}_{3}$ Catalyst Preparation with Impregnation and Microwave Polyol Methods for Bio-Jet Production, Materials Science Forum, Trans Tech Publ, 2020, pp. 257-264.

[77] H. Gu, Y. Yang, J. Tian, G. Shi, Photochemical synthesis of noble metal (Ag, $\mathrm{Pd}, \mathrm{Au}, \mathrm{Pt}$ ) on graphene/ $\mathrm{ZnO}$ multihybrid nanoarchitectures as electrocatalysis for $\mathrm{H}_{2} \mathrm{O}_{2}$ reduction, ACS applied materials \& interfaces 5(14) (2013) 6762-6768.

[78] T. Iqbal, S. Tufail, S. Ghazal, Synthesis of silver, chromium, manganese, tin and iron nano particles by different techniques, International Journal of Nanoscience and Nanotechnology 13(1) (2017) 19-52.

[79] M.A. Salem, E.A. Bakr, H.G. El-Attar, Pt@Ag and Pd@Ag core/shell nanoparticles for catalytic degradation of Congo red in aqueous solution, Spectrochimica Acta Part A: Molecular and Biomolecular Spectroscopy 188 (2018) $155-163$.

[80] M. Moradi, M. Haghighi, S. Allahyari, Precipitation dispersion of Ag-ZnO nanocatalyst over functionalized multiwall carbon nanotube used in degradation of Acid Orange from wastewater, Process Safety and Environmental Protection 107 (2017) 414-427.

[81] C. Duan, C. Liu, X. Meng, W. Lu, Y. Ni, Fabrication of carboxymethylated cellulose fibers supporting Ag NPs@MOF-199s nanocatalysts for catalytic reduction of 4-nitrophenol, Applied Organometallic Chemistry 33(5) (2019) e4865.

[82] K. Iqbal, A. Iqbal, A.M. Kirillov, B. Wang, W. Liu, Y. Tang, A new Ce-doped MgAl-LDH@Au nanocatalyst for highly efficient reductive degradation of organic contaminants, Journal of Materials Chemistry A 5(14) (2017) 6716-6724.

[83] A. Sahoo, S.K. Tripathy, N. Dehury, S. Patra, A porous trimetallic Au@Pd@ Ru nanoparticle system: synthesis, characterisation and efficient dye degradation and removal, Journal of Materials Chemistry A 3(38) (2015) 19376-19383.

[84] M. Nasrollahzadeh, T. Baran, N.Y. Baran, M. Sajjadi, M.R. Tahsili, M. Shokouhimehr, Pd nanocatalyst stabilized on amine-modified zeolite: Antibacterial and catalytic activities for environmental pollution remediation in aqueous medium, Separation and Purification Technology 239 (2020) 116542.

[85] Q. Yan, X.-Y. Wang, J.-J. Feng, L.-P. Mei, A.-J. Wang, Simple fabrication of bimetallic platinum-rhodium alloyed nano-multipods: A highly effective and recyclable catalyst for reduction of 4-nitrophenol and rhodamine B, Journal of Colloid and Interface Science 582 (2021) 701-710.

[86] V. Katoch, N. Sharma, M. Sharma, M. Baghoria, J.J. Panda, M. Singh, B. Prakash, Microflow synthesis and enhanced photocatalytic dye degradation performance of antibacterial Bi 2 O 3 nanoparticles, Environmental Science and Pollution Research (2021) 1-11. 
[87] Y. Dang, Y. Cheng, Y. Zhou, Y. Huang, K. Wang, Nano-PAA-CuCl2 Composite as Fenton-like Reusable Catalyst to Enhanced Degrade Organic Pollutant MB/ MO, Catalysts 11(1) (2021) 10.

[88] A. ur Rehman, M. Aadil, S. Zulfiqar, P.O. Agboola, I. Shakir, M.F. Aly Aboud, S. Haider, M.F. Warsi, Fabrication of binary metal doped $\mathrm{CuO}$ nanocatalyst and their application for the industrial effluents treatment, Ceramics International (2020).

[89] S. Dehghan, M. Tahergorabi, S. Norzaee, E. Boorboor Azimi, M. Hasham Firooz, Y. Dadban Shahamat, Preparation and photocatalytic performance of reduced graphene oxide/ $\mathrm{ZnO}$ nanocatalyst for degradation of metalaxyl from aqueous solution: effect of operational parameters, mineralisation and toxicity bioassay, International Journal of Environmental Analytical Chemistry (2020) 1-23.

[90] M. Dorosti, M. Baghdadi, S. Nasimi, A continuous electroreduction cell composed of palladium nanocatalyst immobilized on discarded cigarette filters as an active bed for $\mathrm{Cr}(\mathrm{VI})$ removal from groundwater, Journal of Environmental Management 264 (2020) 110409.

[91] S.G. Shelar, V.K. Mahajan, S.P. Patil, G.H. Sonawane, Effect of doping parameters on photocatalytic degradation of methylene blue using $\mathrm{Ag}$ doped $\mathrm{ZnO}$ nanocatalyst, SN Applied Sciences 2 (2020) 1-10.

[92] M. Ikram, M.I. Khan, A. Raza, M. Imran, A. Ul-Hamid, S. Ali, Outstanding performance of silver-decorated MoS2 nanopetals used as nanocatalyst for synthetic dye degradation, Physica E: Low-dimensional Systems and Nanostructures 124 (2020) 114246 .

[93] M. Nasrollahzadeh, R. Akbari, Z. Issaabadi, S.M. Sajadi, Biosynthesis and characterization of $\mathrm{Ag} / \mathrm{MgO}$ nanocomposite and its catalytic performance in the rapid treatment of environmental contaminants, Ceramics International 46(2) (2020) 2093-2101.

[94] M. Khoshnamvand, C. Huo, J. Liu, Silver nanoparticles synthesized using Allium ampeloprasum L. leaf extract: Characterization and performance in catalytic reduction of 4-nitrophenol and antioxidant activity, Journal of Molecular Structure 1175 (2019) 90-96.

[95] B. Kumar, K.S. Vizuete, V. Sharma, A. Debut, L. Cumbal, Ecofriendly synthesis of monodispersed silver nanoparticles using Andean Mortiño berry as reductant and its photocatalytic activity, Vacuum 160 (2019) 272-278

[96] V. Garole, B. Choudhary, S. Tetgure, D. Garole, A. Borse, Palladium nanocatalyst: green synthesis, characterization, and catalytic application, International Journal of Environmental Science and Technology 16(12) (2019) 7885-7892.

[97] M. Hashemi Salehi, M. Yousefi, M. Hekmati, E. Balali, Application of palladium nanoparticle-decorated Artemisia abrotanum extract-modified graphene oxide for highly active catalytic reduction of methylene blue, methyl orange and rhodamine B, Applied Organometallic Chemistry 33(10) (2019) e5123.

[98] Z.U.H. Khan, H.M. Sadiq, N.S. Shah, A.U. Khan, N. Muhammad, S.U. Hassan, K. Tahir, F.U. Khan, M. Imran, N. Ahmad, Greener synthesis of zinc oxide nanoparticles using Trianthema portulacastrum extract and evaluation of its photocatalytic and biological applications, Journal of Photochemistry and Photobiology B: Biology 192 (2019) 147-157.

[99] M. Ganesh, S.G. Lee, J. Jayaprakash, M. Mohankumar, H.T. Jang, Hydnocarpus alpina Wt extract mediated green synthesis of $\mathrm{ZnO}$ nanoparticle and screening of its anti-microbial, free radical scavenging, and photocatalytic activity, Biocatalysis and agricultural biotechnology 19 (2019) 101129

[100] A.R. Prasad, J. Garvasis, S.K. Oruvil, A. Joseph, Bio-inspired green synthesis of zinc oxide nanoparticles using Abelmoschus esculentus mucilage and selective degradation of cationic dye pollutants, Journal of Physics and Chemistry of Solids 127 (2019) 265-274.

[101] K. Rajendaran, R. Muthuramalingam, S. Ayyadurai, Green synthesis of Ag$\mathrm{Mo} / \mathrm{CuO}$ nanoparticles using Azadirachta indica leaf extracts to study its solar photocatalytic and antimicrobial activities, Materials Science in Semiconductor Processing 91 (2019) 230-238.

[102] P. Mohammadi, H. Daneshafruz, H. Sheibani, Gold nanoparticles on cyanuric citric acid functionalized magnetic SBA-16 as an effective catalyst for dye reduction, Physica E: Low-dimensional Systems and Nanostructures 126 (2021) 114392

[103] M. Memar, A.R. Rezvani, S. Saheli, Synthesis, characterization, and application of $\mathrm{CuO}$ nanoparticle 2D doped with $\mathrm{Zn} 2+$ against photodegradation of organic dyes (MB \& MO) under sunlight, Journal of Materials Science: Materials in Electronics (2021) 1-19.

[104] A. Nouri, B. Faraji Dizaji, N. Kianinejad, A. Jafari Rad, S. Rahimi, M. Irani, F. Sharifian Jazi, Simultaneous linear release of folic acid and doxorubicin from ethyl cellulose/chitosan $/ \mathrm{g}-\mathrm{C}_{3} \mathrm{~N}_{4} / \mathrm{MoS}_{2}$ core-shell nanofibers and its anticancer properties, Journal of Biomedical Materials Research Part A (2020).

[105] S. Yuan, G. Zhang, J. Zhu, N. Mamrol, S. Liu, Z. Mai, P. Van Puyvelde, B. Van der Bruggen, Hydrogel assisted interfacial polymerization for advanced nano- filtration membranes, Journal of Materials Chemistry A 8(6) (2020) 3238-3245. [106] X. Li, S. Ye, Y.C. Zhang, H.P. Zhao, Y. Huang, B. Zhang, T. Cai, Magnetic Janus nanocomposites with iridium (III) complexes for heterogeneous catalysis of logic controlled RAFT polymerization using multiplexed external switching, Nanoscale 12(14) (2020) 7595-7603.

[107] H. Hu, J.H. Xin, H. Hu, PAM/graphene/Ag ternary hydrogel: synthesis, characterization and catalytic application, Journal of Materials Chemistry A 2(29) (2014) 11319-11333

[108] F. Gorginpour, H. Zali-Boeini, H.A. Rudbari, A quinoxaline-based porous organic polymer containing copper nanoparticles CuNPs@ Q-POP as a robust nanocatalyst toward C-N coupling reaction, RSC Advances 11(6) (2021) 36553665 .

[109] L. Ai, J. Jiang, Catalytic reduction of 4-nitrophenol by silver nanoparticles stabilized on environmentally benign macroscopic biopolymer hydrogel, Bioresource technology 132 (2013) 374-377.

[110] M. Norouzi, D. Elhamifar, Ionic liquid-modified magnetic mesoporous silica supported tungstate: A powerful and magnetically recoverable nanocatalyst, Composites Part B: Engineering 176 (2019) 107308.

[111] Y. Mei, Y. Lu, F. Polzer, M. Ballauff, M. Drechsler, Catalytic activity of palladium nanoparticles encapsulated in spherical polyelectrolyte brushes and coreshell microgels, Chemistry of Materials 19(5) (2007) 1062-1069.

[112] M.I. Din, R. Khalid, Z. Hussain, T. Hussain, A. Mujahid, J. Najeeb, F. Izhar, Nanocatalytic assemblies for catalytic reduction of nitrophenols: a critical review, Critical reviews in analytical chemistry 50(4) (2020) 322-338.

[113] M. J. Thiele, M.D. Davari, M. Konig, I. Hofmann, N.O. Junker, T. Mirzaei Garakani, L. Vojcic, J.r. Fitter, U. Schwaneberg, Enzyme-polyelectrolyte complexes boost the catalytic performance of enzymes, ACS catalysis 8(11) (2018) 10876-10887.

[114] C. Nagahama, A. Zinchenko, Small DNA additives to polyelectrolyte multilayers promote formation of ultrafine gold nanoparticles with enhanced catalytic activity, Colloid and Polymer Science 297(3) (2019) 363-369.

[115] M. Ajmal, M. Siddiq, H. Al-Lohedan, N. Sahiner, Highly versatile p (MAc)-M (M: $\mathrm{Cu}, \mathrm{Co}, \mathrm{Ni})$ microgel composite catalyst for individual and simultaneous catalytic reduction of nitro compounds and dyes, RSC Advances 4(103) (2014) 59562-59570

[116] N. Sahiner, S. Yildiz, H. Al-Lohedan, The resourcefulness of $p$ (4-VP) cryogels as template for in situ nanoparticle preparation of various metals and their use in $\mathrm{H}_{2}$ production, nitro compound reduction and dye degradation, Applied Catalysis B: Environmental 166 (2015) 145-154

[117] R.K. Narayanan, S.J. Devaki, T.P. Rao, Robust fibrillar nanocatalysts based on silver nanoparticle-entrapped polymeric hydrogels, Applied Catalysis A: General 483 (2014) $31-40$

[118] S. Saha, A. Pal, S. Kundu, S. Basu, T. Pal, Photochemical green synthesis of calcium-alginate-stabilized Ag and Au nanoparticles and their catalytic application to 4-nitrophenol reduction, Langmuir 26(4) (2010) 2885-2893.

[119] D. Hu, Y. Huang, H. Liu, H. Wang, S. Wang, M. Shen, M. Zhu, X. Shi, The assembly of dendrimer-stabilized gold nanoparticles onto electrospun polymer nanofibers for catalytic applications, Journal of Materials Chemistry A 2(7) (2014) 2323-2332.

[120] S. Gatard, L. Salmon, C. Deraedt, J. Ruiz, D. Astruc, S. Bouquillon, Gold Nanoparticles Stabilized by Glycodendrimers: Synthesis and Application to the Catalytic Reduction of 4-Nitrophenol, European Journal of Inorganic Chemistry 2014(16) (2014) 2671-2677.

[121] K. Kuroda, T. Ishida, M. Haruta, Reduction of 4-nitrophenol to 4-aminophenol over Au nanoparticles deposited on PMMA, Journal of Molecular Catalysis A: Chemical 298(1-2) (2009) 7-11.

[122] P. Kannan, F.A. Rahim, X. Teng, R. Chen, H. Sun, L. Huang, D.-H. Kim, Enhanced emission of $\mathrm{NaYF}_{4}: \mathrm{Yb}, \mathrm{Er} / \mathrm{Tm}$ nanoparticles by selective growth of $\mathrm{Au}$ and Ag nanoshells, RSC advances 3(21) (2013) 7718-7721.

[123] C. Zhang, Q. Yang, N. Zhan, L. Sun, H. Wang, Y. Song, Y. Li, Silver nanoparticles grown on the surface of PAN nanofiber: Preparation, characterization and catalytic performance, Colloids and Surfaces A: Physicochemical and Engineering Aspects 362(1-3) (2010) 58-64

[124] S. Harish, J. Mathiyarasu, K. Phani, V. Yegnaraman, Synthesis of conducting polymer supported Pd nanoparticles in aqueous medium and catalytic activity towards 4-nitrophenol reduction, Catalysis letters 128(1) (2009) 197-202.

[125] T. Yao, T. Cui, H. Wang, L. Xu, F. Cui, J. Wu, A simple way to prepare Au@ polypyrrole/Fe $3 \mathrm{O} 4$ hollow capsules with high stability and their application in catalytic reduction of methylene blue dye, Nanoscale 6(13) (2014) 7666-7674. [126] K.Ö. Hamaloğlu, E. Sağ, Ç. Kip, E. Şenlik, B.S. Kaya, A. Tuncel, Magnetic-porous microspheres with synergistic catalytic activity of small-sized gold nanoparticles and titania matrix, Frontiers of Chemical Science and Engineering 
13(3) (2019) 574-585.

[127] S. Panigrahi, S. Basu, S. Praharaj, S. Pande, S. Jana, A. Pal, S.K. Ghosh, T. $\mathrm{Pal}$, Synthesis and size-selective catalysis by supported gold nanoparticles: study on heterogeneous and homogeneous catalytic process, The Journal of Physical Chemistry C 111(12) (2007) 4596-4605.

[128] I.U.H. Bhat, M.N.K. Anwar, J.N. Appaturi, Polymer based palladium nanocatalyst for the degradation of nitrate and Congo Red, Journal of Polymers and the Environment 27(7) (2019) 1475-1487.

[129] B. Samai, S.C. Bhattacharya, Conducting polymer supported cerium oxide nanoparticle: Enhanced photocatalytic activity for waste water treatment, Materials Chemistry and Physics 220 (2018) 171-181.

[130] L. Kaliraj, J.C. Ahn, E.J. Rupa, S. Abid, J. Lu, D.C. Yang, Synthesis of panos extract mediated $\mathrm{ZnO}$ nano-flowers as photocatalyst for industrial dye degradation by UV illumination, Journal of Photochemistry and Photobiology B: Biology 199 (2019) 111588.

[131] M. Nasrollahzadeh, B. Jaleh, T. Baran, R.S. Varma, Efficient degradation of environmental contaminants using Pd-RGO nanocomposite as a retrievable catalyst, Clean Technologies and Environmental Policy 22(2) (2020) 325-335.

[132] X. Peng, X. Bai, Z. Cui, X. Liu, Green synthesis of Pd truncated octahedrons using of firmiana simplex leaf extract and their catalytic study for electro-oxidation of methanol and reduction of p-nitrophenol, Applied Organometallic Chemistry 33(8) (2019) e5045.

[133] S. Bao, H. Liu, Y. Liu, W. Yang, Y. Wang, Y. Yu, Y. Sun, K. Li, Amino-functionalized graphene oxide-supported networked $\mathrm{Pd}-\mathrm{Ag}$ nanowires as highly efficient catalyst for reducing $\mathrm{Cr}(\mathrm{VI})$ in industrial effluent by formic acid, Chemosphere 257 (2020) 127245.

[134] M.N. Chong, B. Jin, C.W. Chow, C. Saint, Recent developments in photocatalytic water treatment technology: a review, Water research 44(10) (2010) 2997-3027.

[135] A. Jaafara, A. Driouichb, Z. Lakbaibib, H.B. El Ayouchiac, K. Azzaouid, A. Boussaouda, S. Jodehe, Central composite design for the optimization of Basic Red V degradation in aqueous solution using Fenton reaction, Desalination and Water Treatment 158 (2019) 364-371.

[136] A. Jaafar, H.B. El Ayouchia, Z. Lakbaibi, A. Boussaoud, S. Jodeh, K. Azzaoui, M. Tabyaoui, Degradation of Pollutant Dye in Aqueous Solution using Fenton Reaction: A DFT Study, GP GLOBALIZE RESEARCH JOURNAL OF CHEMISTRY (2019).

[137] H. Eskandarloo, A. Kierulf, A. Abbaspourrad, Nano-and micromotors for cleaning polluted waters: focused review on pollutant removal mechanisms, Nanoscale 9(37) (2017) 13850-13863.

[138] K. Shivaji, E.S. Monica, A. Devadoss, D.D. Kirubakaran, C.R. Dhas, S.M Jain, S. Pitchaimuthu, Synthesizing Green Photocatalyst Using Plant Leaf Extract for Water Pollutant Treatment, Green Photocatalysts, Springer2020, pp. 25-46. [139] A.A. Yaqoob, T. Parveen, K. Umar, M.N. Mohamad Ibrahim, Role of nano- materials in the treatment of wastewater: A review, Water 12(2) (2020) 495.

[140] A. Moghanian, F. Sharifianjazi, P. Abachi, E. Sadeghi, H. Jafarikhorami, A. Sedghi, Production and properties of $\mathrm{Cu} / \mathrm{TiO}_{2}$ nano-composites, Journal of Alloys and Compounds 698 (2017) 518-524.

[141] S. Kabra, S. Gharde, P. Gore, S. Jain, V.H. Khire, B. Kandasubramanian, Recent trends in nanothermites: Fabrication, characteristics and applications, Nano Express (2020).

[142] T. Toyao, M. Saito, Y. Horiuchi, K. Mochizuki, M. Iwata, H. Higashimura, M. Matsuoka, Efficient hydrogen production and photocatalytic reduction of nitrobenzene over a visible-light-responsive metal-organic framework photocatalyst, Catalysis Science \& Technology 3(8) (2013) 2092-2097.

[143] Y. Pi, X. Li, Q. Xia, J. Wu, Y. Li, J. Xiao, Z. Li, Adsorptive and photocatalytic removal of Persistent Organic Pollutants (POPs) in water by metal-organic frameworks (MOFs), Chemical Engineering Journal 337 (2018) 351-371.

[144] T. Saeed, A. Naeem, I.U. Din, M.A. Alotaibi, A.I. Alharthi, I.W. Khan, N.H. Khan, T. Malik, Structure, nomenclature and viable synthesis of micro/nanoscale metal organic frameworks and their remarkable applications in adsorption of organic pollutants, Microchemical Journal (2020) 105579.

[145] M. Nasrollahzadeh, M. Sajjadi, S. Iravani, R.S. Varma, Green-synthesized nanocatalysts and nanomaterials for water treatment: Current challenges and future perspectives, Journal of Hazardous Materials 401 (2021) 123401.

[146] A. Mukhtar, S. Ullah, A.G. Al-Sehemi, M.A. Assiri, S. Saqib, R. Amen, M. Babar, M.A. Bustam, T. Ahmad, Synthesis and Stability of Metal-organic Frameworks (MOFs) Photocatalysts for the Removal of Persistent Organic Pollutants (POPs) from Wastewater, Current Analytical Chemistry 17(1) (2021) 61-81.

[147] F.S. Jazi, N. Parvin, M. Rabiei, M. Tahriri, Z.M. Shabestari, A.R. Azadmehr, Effect of the synthesis route on the grain size and morphology of $\mathrm{ZnO} / \mathrm{Ag}$ nanocomposite, Journal of Ceramic Processing Research 13(5) (2012) 523-526.

[148] Y. Zhang, J. Zhou, X. Chen, Q. Feng, W. Cai, MOF-derived C-doped ZnO composites for enhanced photocatalytic performance under visible light, Journal of Alloys and Compounds 777 (2019) 109-118.

[149] M.C. Das, H. Xu, Z. Wang, G. Srinivas, W. Zhou, Y.-F. Yue, V.N. Nesterov, G. Qian, B. Chen, A Zn 4 O-containing doubly interpenetrated porous metal-organic framework for photocatalytic decomposition of methyl orange, Chemical Communications 47(42) (2011) 11715-11717.

[150] T. Parandhaman, N. Pentela, B. Ramalingam, D. Samanta, S.K. Das, Metal nanoparticle loaded magnetic-chitosan microsphere: water dispersible and easily separable hybrid metal nano-biomaterial for catalytic applications, ACS Sustainable Chemistry \& Engineering 5(1) (2017) 489-501.

[151] M. Abdeen, S. Sabry, H. Ghozlan, A.A. El-Gendy, E.E. Carpenter, Microbial-physical synthesis of $\mathrm{Fe}$ and $\mathrm{Fe}_{3} \mathrm{O}_{4}$ magnetic nanoparticles using Aspergillus niger YESM1 and supercritical condition of ethanol, Journal of Nanomaterials 2016 (2016). 